\title{
Prevalence of Algal Toxins in Alaskan Marine Mammals Foraging in a Changing
}

\section{Arctic and Subarctic Environment}

3 Kathi A. Lefebvre ${ }^{1 *}$, Lori Quakenbush ${ }^{2}$, Elizabeth Frame $^{1,3}$, Kathy Burek Huntington ${ }^{4}$,

4 Gay Sheffield ${ }^{5}$, Raphaela Stimmelmayr ${ }^{6}$, Anna Bryan $^{2}$, Preston Kendrick ${ }^{1}$, Heather Ziel $^{7}$,

5 Tracey Goldstein ${ }^{8}$, Jonathan A. Snyder ${ }^{9}$, Tom Gelatt ${ }^{7}$, Frances Gulland ${ }^{10}$, Bobette

6

Dickerson $^{7}$, Verena Gill ${ }^{9,11}$

$7 \quad{ }^{1}$ Northwest Fisheries Science Center, NOAA Fisheries, Seattle, WA

$8{ }^{2}$ Alaska Department of Fish and Game, Arctic Marine Mammal Program, 1300 College

9 Road, Fairbanks, AK

$10{ }^{3}$ Current: Aquatic Toxiclogy Unit, King County Environmental Laboratory, Seattle, WA

$11{ }^{4}$ Alaska Veterinary Pathology Services (AVPS), 23834 The Clearing Drive, Eagle River,

12 AK

$13{ }^{5}$ University of Alaska Fairbanks, Alaska Sea Grant, Marine Advisory Program, PO Box

14400 , Nome, AK

$15{ }^{6}$ North Slope Borough Department of Wildlife Management, PO Box 69, Barrow, AK

$16{ }^{7}$ Marine Mammal Laboratory, Alaska Fisheries Science Center, NOAA, Seattle, WA

$17{ }^{8}$ One Health Institute, School of Veterinary Medicine, University of California, Davis,

18 CA

$19{ }^{9}$ U.S. Fish and Wildlife Service, Marine Mammals Management, 1011 East Tudor Rd.,

20 Anchorage, AK

$21{ }^{10}$ The Marine Mammal Center, 2000 Bunker Road, Fort Cronkhite, Sausalito, CA

$22{ }^{11}$ Current: Bureau of Ocean Energy Management, 3801 Centerpoint Dr., Anchorage, AK

$23 *$ Corresponding Author: Kathi.Lefebvre@ noaa.gov 


\section{Abstract:}

2 Current climate trends resulting in rapid declines in sea ice and increasing water

3 temperatures are likely to expand the northern geographic range and duration of favorable

4 conditions for harmful algal blooms (HABs), making algal toxins a growing concern in

5 Alaskan marine food webs. Two of the most common HAB toxins along the west coast of

6 North America are the neurotoxins domoic acid (DA) and saxitoxin (STX). Over the last

720 years, DA toxicosis has caused significant illness and mortality in marine mammals

8 along the west coast of the USA, but has not been reported to impact marine mammals

9 foraging in Alaskan waters. Saxitoxin, the most potent of the paralytic shellfish poisoning

10 toxins, has been well-documented in shellfish in the Aleutians and Gulf of Alaska for

11 decades and associated with human illnesses and deaths due to consumption of toxic

12 clams. There is little information regarding exposure of Alaskan marine mammals. Here,

13 the spatial patterns and prevalence of DA and STX exposure in Alaskan marine mammals

14 are documented in order to assess health risks to northern populations including those

15 species that are important to the nutritional, cultural, and economic well-being of Alaskan

16 coastal communities. In this study, 905 marine mammals from 13 species were sampled

17 including; humpback whales, bowhead whales, beluga whales, harbor porpoises,

18 Northern fur seals, Steller sea lions, harbor seals, ringed seals, bearded seals, spotted

19 seals, ribbon seals, Pacific walruses, and northern sea otters. Domoic acid was detected in

20 all 13 species examined and had the greatest prevalence in bowhead whales (68\%) and

21 harbor seals (67\%). Saxitoxin was detected in 10 of the 13 species, with the highest

22 prevalence in humpback whales $(50 \%)$ and bowhead whales (32\%). Pacific walruses

23 contained the highest concentrations of both STX and DA, with DA concentrations 
1 similar to those detected in California sea lions exhibiting clinical signs of DA toxicosis

2 (seizures) off the coast of Central California, USA. Forty-six individual marine mammals

3 contained detectable concentrations of both toxins emphasizing the potential for

4 combined exposure risks. Additionally, fetuses from a beluga whale, a harbor porpoise

5 and a Steller sea lion contained detectable concentrations of DA documenting maternal

6 toxin transfer in these species. These results provide evidence that HAB toxins are

7 present throughout Alaska waters at levels high enough to be detected in top predators

8 and have the potential to impact marine mammal health in the Arctic marine

9 environment.

\section{1. Introduction}

12 Harmful algal blooms (HABs) most commonly occur in temperate and tropical

13 regions; however, current climate trends such as ocean warming and loss of seasonal sea

14 ice, are likely to expand the geographic distribution and the duration of conditions that

15 support blooms (Moore et al., 2008; Van Dolah, 2000), making HAB exposure

16 potentially more common among marine mammals in Alaskan waters (Burek et al.,

17 2008). Species of phytoplankton known to be toxic are not new to Alaskan waters.

18 Diatoms of the genus Pseudo-nitzschia, have been documented as far north as the eastern

19 Beaufort Sea (Bursa, 1963) and produce domoic acid (DA), the toxin responsible for

20 amnesic shellfish poisoning (ASP). Domoic acid was first detected in low levels in razor

21 clams in Kachemak Bay in July 1992 (RaLonde and Wright, 2011). Dinoflagellates of the

22 genus Alexandrium produce toxins that cause paralytic shellfish poisoning (PSP) and

23 have been well documented in Alaskan waters (Gessner and Middaugh, 1995; Gessner et 
1 al., 1997; Gessner and Schloss, 1996; Lewitus et al., 2012; Trainer et al., 2014). Saxitoxin

2 (STX) is the most potent of the PSP causing toxins. Both DA and STX affect the central

3 nervous system of vertebrates. Saxitoxin acts as a sodium channel blocker and prevents

4 action potential activity in nerves causing paralysis primarily of the respiratory system

5 (Cusick and Sayler, 2013). Domoic acid is an excitotoxin that over-stimulates glutamate

6 receptors in the vertebrate central nervous system causing stimulation of nerves (Berman

7 et al., 2002; Berman and Murray, 1997; Todd, 1993). While PSP has been documented in

8 humans in Alaska since 1799, the only documented cases of ASP in humans occurred in

9 Southeastern Canada in 1989 (Perl et al., 1990). Unlike temperate regions, no incidences

10 of DA toxicosis and very few incidences of STX toxicosis have been documented in

11 Alaskan marine mammals.

12 Ocean temperatures around Alaska are warming; shelf waters of the eastern

13 Bering Sea have increased by almost $3^{\circ} \mathrm{C}$ during the past decade (Stabeno et al., 2007).

14 The lowest sea ice extent measurements since satellite monitoring began in 1979 were

15 recorded during 2007-2009 ((Stroeve et al., 2008) National Snow and Ice Data Center

16 press release, October 6, 2009), until 2012, which is the record Arctic sea ice minimum

17 documented to date. Loss of sea ice has allowed industrial maritime ship traffic across the

18 Arctic to increase substantially. Ships can transport HAB species to new areas through

19 ballast water discharge (Reeves et al., 2012), a process that is currently unregulated in the

20 Arctic (Hallegraeff, 1998). Filter-feeding benthic invertebrates, zooplankton, and finfish

21 can accumulate STX and DA and are well-known vectors of algal toxins to higher trophic

22 level predators (Bargu et al., 2002; Costa et al., 2009; Lefebvre et al., 2002b; Wekell et

23 al., 1994; White, 1986; Wohlgeschaffen et al., 1992). 
The potential for health effects on Alaskan marine mammals may be high

2 considering more than $40 \%$ of marine mammal unusual mortality events (UMEs) in the

3 contiguous USA during the last 20 years have been attributed to algal toxin exposure

4 (Flewelling et al., 2005; Gulland and Hall, 2007; Landsberg et al., 2014; Scholin et al.,

5 2000; Torres De La Riva et al., 2009). The number of HAB-related strandings appears to

6 be increasing in the contiguous USA as these events were relatively rare even in

7 temperate regions only two decades ago (Landsberg et al., 2014). The negative impacts of

8 algal toxins on marine mammal health have been well documented along the west coast

9 of the USA. For example, the neurotoxic effects of DA were first reported in stranded

10 California sea lions (Zalophus californianus) in 1998 through exposure from toxic

11 planktivorous prey such as northern anchovies and Pacific sardines (Gulland, 2000;

12 Lefebvre et al., 1999; Scholin et al., 2000). Clinical signs of acute DA poisoning in

13 marine mammals include ataxia, head weaving, seizures or coma and/or death (Gulland et

14 al., 2002). The frequency of DA-associated California sea lion strandings has increased

15 since 1998 and strandings now occur annually, affecting hundreds of sea lions per year

16 (Bargu et al., 2010). Additionally, a chronic neurological syndrome associated with

17 repetitive sub-lethal exposure to the toxin is now recognized by behavioral changes,

18 seizures, and atrophy of the hippocampal formation (Cook et al., 2015; Goldstein et al.,

19 2008). Domoic acid has also been documented to cross the placenta of California sea

20 lions and be present in milk, thus, neonates may be exposed in utero and after birth until

21 weaning (Brodie et al., 2006; Rust et al., 2014). In addition to contributing to

22 reproductive failure, in utero and lactational exposure to DA can result in developmental

23 abnormalities leading to neurological and behavioral deficits in surviving offspring. 
1 Given that California sea lions and humans share a common prey base, sea lions serve as

2 important food safety sentinels regarding the presence of HABs near California. The

3 findings associated with DA exposure in California sea lions demonstrate the potential

4 health effects for other marine mammal species, as well as the potential for marine

5 mammals in other regions to be sentinels for public health threats. The effects of STX on

6 marine mammals are not as well documented as they are for DA. The first reported STX-

7 related mortality event involved humpback whales in the late 1980s when 14 humpback

8 whales died near Cape Cod Bay after ingesting mackerel containing STX (Geraci et al.,

9 1989). Saxitoxin was suspected (although not substantiated) to be a factor in 60 sea otter

10 deaths in Alaska (Degange and Vacca, 1989) and in 117 Mediterranean monk seal

11 (Monachus monachus) deaths in Western Sahara, Africa (Costas and Lopez-Rodas, 12 1998).

13 The goal of this study was to document the presence and extent of two algal

14 toxins (DA and STX) in Alaskan marine mammals to identify emerging exposure risks in

15 northern-ranging marine mammal populations, including those species that are important

16 to people for subsistence purposes. Thirteen species were examined including: four

17 cetaceans (humpback whales, Megaptera novaeangliae; bowhead whales, Balaena

18 mysticetus; beluga whales, Delphinapterus leucas; and harbor porpoises, Phocoena

19 phocoena), two otariids (northern fur seals, Callorhinus ursinus and Steller sea lions,

20 Eumetopias jubatus), five phocids (harbor, Phoca vitulina; ringed P. hispida; bearded,

21 Erignathus barbatus; spotted, P. largha and ribbon seals, Histriophoca fasciata), Pacific

22 walruses (Odobenus rosmarus), and northern sea otters (Enhydra lutra).

\section{2. Methods}




\section{$12.1 \quad$ Marine mammal sample collection:}

2 A variety of samples (feces, stomach contents, intestinal contents, serum, milk,

3 urine, amniotic fluid, bile, aqueous humor, and pleural, peritoneal and pericardial fluid)

4 were collected from Alaskan marine mammals that were stranded, harvested for

5 subsistence purposes, or captured for research. Samples were also collected during the

6 Northern Alaska Pinniped Unusual Mortality Event (UME)

7 (http://www.nmfs.noaa.gov/pr/health/mmume/events.html). Not all sample types were

8 collected from each animal. The majority of the samples consisted of feces, urine, serum

9 and stomach and intestinal contents. Samples were frozen as soon as possible after

10 collection to prevent degradation, although some stranded animals had various levels of

11 degradation. Samples were stored frozen until shipped to the Northwest Fisheries Science

12 Center's Wildlife Algal-Toxin Research and Response Network (WARRN-West)

13 laboratory (Seattle, WA, USA) for algal toxin testing. All live and stranded animal

14 handling was consistent with approved humane practices under the following permits:

15 Marine Mammal Protection Act (MMPA) permit number MA041309-5, and National

16 Marine Fisheries (NMFS) research permit numbers 358-1787, 15324, and 10091. A

17 summary of the total number of animals, collection period, and locations is shown in

18 Table 1. Additional detailed information on sample collection is provided in the sections

19 below.

21 2.1.1 Humpback whale fecal, stomach and intestinal contents, aqueous humor, pleural

22 fluid, and urine samples ( $n=8$ animals): During 2007-2011, samples were collected

23 from stranded humpback whales from Southeast Alaska $(n=5)$, Kodiak $(n=2)$ and The 
1 Alaska Peninsula $(n=1)$. Samples were stored frozen in Whirl-Pak® bags at -40 or -80

$2 \quad{ }^{\circ} \mathrm{C}$ until analyzed for algal toxins.

4 2.1.2 Bowhead whale fecal samples ( $n=25$ animals): During 2006-2011, fecal samples

5 from bowhead whales harvested for subsistence purposes were collected during the

6 spring and fall in Barrow, Alaska. Sections of colon were cut and fecal matter was

7 removed using plastic spoons. Samples were stored frozen in Whirl-Pak ${ }^{\circledR}$ bags at $-20{ }^{\circ} \mathrm{C}$

8 until analyzed for algal toxins.

10 2.1.3 Beluga whale fecal, stomach contents, amniotic fluid, pericardial fluid, and urine

11 samples ( $n=15$ animals): During 2007-2012, samples were collected from stranded

12 Cook Inlet beluga whales. Three females were pregnant and samples were collected from

13 both the mother and the fetus in all three cases. Stomachs from two belugas harvested for

14 subsistence purposes at Hooper Bay were also collected. Samples were stored frozen in

15 Whirl-Pak $®$ bags at -40 or $-80{ }^{\circ} \mathrm{C}$ until analyzed for algal toxins.

17 2.1.4 Harbor porpoise fecal, stomach and intestinal contents, aqueous humor, and

18 urine ( $n=5$ animals): During 2010-2013, samples were collected from five stranded

19 harbor porpoises from Cook Inlet, with both mother and fetus analyzed in one case.

20 Samples included feces $(\mathrm{n}=2)$, aqueous humor $(\mathrm{n}=1)$, stomach $(\mathrm{n}=1)$ and intestinal

21 contents $(\mathrm{n}=1)$, and urine $(\mathrm{n}=2)$ with some animals having multiple sample types

22 analyzed. Samples were stored in Whirl-Pak ${ }^{\circledR}$ bags at -40 or $-80{ }^{\circ} \mathrm{C}$ until analyzed for

23 algal toxins. 
2 2.1.5 Northern fur seal fecal and serum samples $(n=179$ animals $)$ : Between 7-15

3 October 2010, serum samples were collected from 131 live-captured adult female

4 northern fur seals with pups on Saint George Island (Pribilof Islands) and fecal samples

5 were collected from 48 northern fur seals harvested on Saint Paul Island (Pribilof Islands)

6 for subsistence purposes. Samples were frozen in cryovials or Whirl-Pak® bags and

$7 \quad$ stored at $-20{ }^{\circ} \mathrm{C}$ until analyzed for algal toxins.

8

9 2.1.6 Steller sea lion fecal, stomach and intestinal contents, amniotic, pleural,

10 peritoneal and pericardial fluid, bile, and urine samples $(n=42$ animals $)$ : During 2004-

11 2013, samples were collected from 42 stranded Steller sea lions, some of which were

12 rookery pups and aborted fetuses on rookeries. Stranded animals were sampled across

13 Alaska from southeast Alaska through Prince William Sound and through the Aleutian

14 Islands. Samples were collected in amber vials (bile), Whirl-Pak® bags (feces, and

15 stomach and intestinal contents) and cryovials (urine, and amniotic, pleural, peritoneal

16 and pericardial fluid) and stored at $-80{ }^{\circ} \mathrm{C}$ until analyzed for algal toxins.

18 2.1.7 Harbor seal bile, feces, aqueous humor, placenta, and urine samples $(n=9$

19 animals): During 2008-2012, samples were collected from nine stranded harbor seals;

20 three in Southeast Alaska (Bartlett Cove in Glacier Bay, Lynn Canal, and Sitka), four in

21 Southcentral Alaska (Kachemak Bay, Resurrection Bay, Kenai, and Cook Inlet), one in

22 Southwest Alaska (Izembek Lagoon), and one in Bristol Bay (Egegik). Samples were 
1 collected in amber vials (bile), Whirl-Pak ${ }^{\circledR}$ bags (feces and placenta) or cryovials

2 (aqueous humor and urine) and stored at $-60^{\circ} \mathrm{C}$ until analyzed.

$4 \quad 2.1 .8$ Ice seals (ringed $(n=113)$, bearded $(n=55)$, spotted $(n=158)$, and ribbon seals

$5(n=21))$ stomach/intestinal contents, fecal, and urine samples: During 2006-2013,

6 samples from ice seals harvested during spring and fall for subsistence purposes were

7 collected from the coastal communities of Hooper Bay, Savoonga, Gambell, Little

8 Diomede, Shishmaref, Kotzebue, Point Hope, Wainwright, and Barrow in the Bering

9 Strait region and Chukchi Sea. Whole stomachs or a piece of intestine were collected in

10 Ziploc® bags. Urine was collected in a centrifuge tube. All samples were frozen and

11 shipped to the Alaska Department of Fish and Game (ADF\&G) laboratory in Fairbanks

12 and stored at $-20^{\circ} \mathrm{C}$. Stomachs and intestines were thawed and $5 \mathrm{ml}$ of content was

13 removed from each, placed in centrifuge tubes with screw caps, and refrozen. During

14 May of 2009-2010, live captures were conducted by the National Marine Mammal Lab

15 (Alaska Fisheries Science Center's Polar Ecosystems Program) and samples were

16 obtained from ice floes and collected using a metal shovel to scoop the urine soaked ice

17 which was placed in Whirl-Pak® bags and frozen at $-80^{\circ} \mathrm{C}$ until analyzed for algal toxins.

19 2.1.9 Pacific walrus stomach and intestinal content samples $(n=82$ animals): During

20 May 2012-2013, stomach and intestinal contents were collected from walruses harvested

21 for subsistence purposes from the coastal communities of Gambell and Savoonga on

22 Saint Lawrence Island. Hunters collected the samples in situ and brought them to shore

23 where they were frozen on site at $-18^{\circ} \mathrm{C}$ and shipped to the $\mathrm{ADF} \& \mathrm{G}$ laboratory in 
1 Fairbanks and subsequently stored at $-20^{\circ} \mathrm{C}$ until algal toxin analysis. Stomachs and

2 intestines were thawed and $5 \mathrm{ml}$ of content was removed and placed in centrifuge tubes

3 with screw tops and refrozen.

4

5 2.1.10 Sea otter urine, pericardial fluid, and maternal milk samples ( $n=193$ animals):

6 From 2004-2011, samples were collected from Northern sea otter carcasses $(n=172)$

7 recovered in the Gulf of Alaska and Aleutian Islands - notably Sitka, Juneau, Glacier

8 Bay, Yakutat Bay, Prince William Sound, lower Kenai Peninsula, lower Cook Inlet,

9 Kodiak, eastern Aleutians, and Cold Bay. Additionally, urine samples $(\mathrm{n}=21)$ were

10 collected during 2011 from live-captured otters from the northern end of Kuiu Island in

11 the southern Gulf of Alaska. Samples were collected and stored at $-20^{\circ} \mathrm{C}$ until analyzed

12 for algal toxins.

$142.2 \quad$ Sample extraction for toxin analysis:

15 All samples were thawed at room temperature. Depending on the amount of

16 sample available, $1-4 \mathrm{~g}$ was weighed out or 1-4 $\mathrm{ml}$ was aliquoted into a $15 \mathrm{ml}$

17 polypropylene screw-cap tube (Falcon-BD). The initial extraction step was carried out by

18 adding 50\% aqueous methanol (for DA extraction) or 80\% ethanol (for STX extraction)

19 to the sample in a 1:4 wt/wt ratio (1 part sample, 3 parts solvent) and thoroughly

20 vortexing the sample. For fecal material, stomach contents and intestinal contents,

21 samples were homogenized for at least 60 seconds using an Omni ES homogenizer. The

22 homogenized sample was then centrifuged at 10,000 x g (Sorvall RC 5C Plus centrifuge)

23 for 20 minutes at $4^{\circ} \mathrm{C}$. The supernatant was then filtered through a $0.22 \mu \mathrm{m}$ membrane 
1 microcentrifuge tube filter (Millipore Ultrafree-MC centrifugal concentration device,

2 Durapore membrane, $0.22 \mu \mathrm{m}$ pore size) and spun in a desk-top microcentrifuge

3 (Eppendorf model 5415C) for at least 10 minutes at a setting of 14. For urine, serum and

4 other body fluids, samples were sonicated (Branson Sonifier 450) at 50\% pulse for 45

5 seconds at a setting of 5. Samples were then centrifuged at 10,000 $\mathrm{x} g$ for 20 minutes at

$64^{\circ} \mathrm{C}$. The supernatant was then filtered through a $25 \mathrm{~mm}$ diameter, $0.45 \mu \mathrm{m}$ pore size

7 syringe filter (Pall Gelman Acrodisc PSF G x F with GHP membrane). All sample

8 extracts were stored at $4^{\circ} \mathrm{C}$ until analysis by ELISA.

102.3 Quantification of algal toxins in marine mammal extracts:

11 Algal toxins were quantified using commercially available enzyme-linked

12 immunosorbent assay (ELISA) kits; Biosense ${ }^{\circledR}$ DA ELISA for DA and Abraxis saxitoxin

13 ELISA for STX, following the instruction protocol supplied by the manufacturer

14 (Biosense ${ }^{\circledR}$ Laboratories, Bergen, Norway and Abraxis LLC, Warminster, PA) with slight

15 modifications based on sample matrix. These kits were originally developed for testing

16 shellfish rather than marine mammal samples. Consequently, testing in order to

17 determine matrix effects for feces, stomach and intestinal contents, urine, bile, aqueous

18 humor, serum, and milk were performed in a previous study (Lefebvre et al., 2010). For

19 DA ELISAs, the minimum dilutions of the 1:4 50\% MeOH extracts required to eliminate

20 all matrix effects were 1:100 for feces and bile, 1:50 for milk and stomach and intestinal

21 contents, and 1:10 for urine, aqueous humor and serum, using our extraction methods and

22 ELISA kits. For STX ELISAs, a 1:50 dilution of the 1:4 80\% ethanol extracts was

23 sufficient to eliminate matrix effects in all sample types. Additionally, the Abraxis 
1 ELISA kit is designed to measure only STX (with some limited cross-reactivity to several

2 other PSP toxins, as listed in the Abraxis product documents), consequently all PSP

3 levels are listed as STX equivalents and as such, may underestimate the presence of other

4 congeners. With these minimum dilutions, the detection limits for DA in sample material

5 were, $4 \mathrm{ng} / \mathrm{g}$ or $\mathrm{ml}$ for feces and bile, $2 \mathrm{ng} / \mathrm{g}$ or $\mathrm{ml}$ for stomach and intestinal contents and

6 milk, and $0.4 \mathrm{ng} / \mathrm{ml}$ urine, aqueous humor and serum. The detection limit for STX in all

$7 \quad$ sample matrices was $3 \mathrm{ng} / \mathrm{ml}$.

8

9 3. Results

10 Algal toxins were detected in at least one animal from all 13 species of marine

11 mammals sampled $(\mathrm{n}=905$ total animals; Tables 2 and 3$)$. In addition, 46 individuals

12 contained detectable concentrations of both DA and STX, including three of eight

13 humpbacks, six of 25 bowheads, five of 110 ringed seals, three of 44 bearded seals, and

1420 of 82 walruses tested for both toxins (Table 4). Saxitoxin and DA were present in

15 marine mammals sampled throughout our study area, from the southeastern Gulf of

16 Alaska to the eastern Beaufort Sea (Figure 1). Domoic acid was detected in more animals

17 (Table 2) and species (all 13) than STX (10 species; Table 3).

$19 \quad 3.1 \quad$ Domoic acid

20 Bowhead whales had the greatest prevalence of DA (68\%), followed by harbor

21 seals (67\%), walruses (41\%), harbor porpoises (40\%), humpback whales (38\%), Steller

22 sea lions (27\%), bearded seals (25\%), northern sea otters (25\%), ribbon seals (24\%),

23 ringed seals (17\%), beluga whales (13\%), northern fur seals (5\%), and spotted seals (3\%; 
1 Table 2). The highest concentrations were found in feces, stomach contents, intestinal

2 contents, and urine (Table 2). The maximum DA concentration detected was from the

3 intestinal contents of a 15 -year-old female walrus $(6,457 \mathrm{ng} / \mathrm{g})$ from the northern Bering

4 Sea. Domoic acid was also detected in three fetuses (one beluga, one harbor porpoise and

5 one Steller sea lion). Figure 2 shows all DA positive fecal, gastrointestinal, and urine

6 samples for all species examined. Additionally, DA concentrations in feces and urine

7 from ten California sea lions (CSLs) sampled from the central California coast that were

8 exhibiting clinical signs of DA toxicosis (seizures) are shown in red in Figure 2 for

9 comparison. These CSLs were selected from Appendix A, Table 1 of a report on toxin

10 detection methods for marine mammals where both urine and feces were analyzed for

11 comparison in multiple animals (Frame and Lefebvre, 2012). The identification numbers

12 were used to access the Marine Mammal Center Database to determine which animals

13 were observed to have seizures.

\section{$15 \quad 3.2 \quad$ Saxitoxin}

16 Humpback whales had the greatest prevalence of STX (50\%), followed by

17 bowhead whales (32\%), walruses (28\%), northern sea otters (23\%), ringed seals (14\%),

18 bearded seals (14\%), Steller sea lions (10\%), beluga whales (8\%), northern fur seals

19 (5\%), and spotted seals (1\%; Table 3). The highest STX concentrations were detected in

20 feces, stomach and intestinal contents, and urine (Table 3). The maximum STX

21 concentration was detected from the intestinal contents of a 21-year-old male walrus (240

22 ng STX equiv./g; Table 3) from the northern Bering Sea. Additionally, this walrus also

23 contained a high concentration of DA $(991 \mathrm{ng} / \mathrm{g})$ in the intestinal contents sample. 


\section{4. Discussion}

3 The number of species and the extensive geographic range in which DA and STX

4 were detected demonstrates that HABs are present throughout Alaska's marine

5 environment and thus the potential for health effects due to exposure is present for all 13

6 Alaskan marine mammal species tested in this study. For adult marine mammals, DA and

$7 \quad$ STX are being ingested through prey, however, in the case of DA, fetuses and suckling

8 young can also be exposed through amniotic fluid and milk (Rust et al., 2014). Maternal

9 transfer of DA has been well documented by laboratory studies and natural

10 environmental exposures with California sea lions (Maucher and Ramsdell, 2005;

11 Maucher and Ramsdell, 2007; Ramsdell and Zabka, 2008). In the present study, one

12 beluga whale fetus, one harbor porpoise fetus, and one Steller sea lion fetus contained

13 detectable concentrations of DA in stomach contents and feces, further documenting the

14 risk of maternal transfer of toxins from pregnant females with environmental exposures

15 to these biotoxins. Additionally, several sea otter pups and harbor seal neonates contained

16 detectable concentrations of DA, however whether they were actively nursing is

17 unknown. The diets of the 13 species tested in this study are varied due to their diverse

18 marine mammal life histories and range from zooplankton, to benthic invertebrates, to

19 finfish.

20

$214.1 \quad$ Cetaceans

22 4.1.1 Humpback whales: In Alaska, humpback whales seasonally range from the

23 southern Gulf of Alaska to the Chukchi Sea during the summer months. During winter 
1 they migrate south to Mexico, Baja California and the Hawaiian Islands to breed and

2 calve. Feeding in cooler Alaskan waters typically occurs during the spring, summer and

3 fall months (Baker et al., 1986). There may be resident populations of humpback whales

4 in the southeastern Gulf of Alaska. In Alaska, their diet consists of krill and many

5 different kinds of fish including herring (Clupea pallasii) and capelin (Mallotus villosus);

6 all of which are planktivorous and therefore likely vectors of DA and STX (Bargu et al.,

7 2002; Doucette et al., 2005; Lefebvre et al., 2002a). A lower percentage of humpbacks

8 tested positive for DA ( $38 \%$, highest concentration $=51 \mathrm{ng} / \mathrm{g}$ feces) (Table 2) than STX

$9(50 \%$, highest concentration $=62 \mathrm{ng} / \mathrm{g})($ Table 3$)$. The highest DA and STX

10 concentrations were found in an individual that died from a ship strike, which may not be

11 a coincidence because STX and DA intoxication have been suggested to be a factor in the

12 loss of ability to avoid ships and to be a cause of stranding (Geraci et al., 1989).

14 4.1.2 Bowhead whales: The entire population of western Arctic bowhead whales

15 ranges through Arctic Alaskan waters from the central Bering Sea to the Canadian

16 Beaufort Sea during their annual migration cycle. Bowhead whales are an important

17 subsistence species for western and northern Alaska providing more than ten villages

18 with substantial meat and blubber each year. This stock of bowhead whales is listed as

19 endangered under the Endangered Species Act (ESA), however the population is

20 increasing (3\% annually) and believed to have recovered substantially (George et al.,

21 2004; Gerber et al., 2007; Givens et al., 2013; Zeh and Punt, 2005), suggesting that the

22 current reduction in sea ice has had no detectable negative effects on population growth.

23 Bowheads feed on small zooplankton consisting mainly of calanoid copepods and 
1 euphausiids, both of which consume phytoplankton (Moore et al., 2010) and are likely

2 the source of the high occurrence rates of DA (68\%) and STX (32\%) in fecal samples.

$4 \quad$ 4.1.3 Beluga whales: In Alaska, there are four stocks of beluga whales, which

5 range from the Bering Sea to the Canadian Beaufort Sea. These stocks are abundant and

6 support subsistence harvests. In addition, there is a fifth stock in Cook Inlet, a tidal

7 estuary located in the northern Gulf of Alaska. All but two of the animals sampled were

8 part of the Cook Inlet stock. This stock is the most genetically isolated (O'Corry-Crowe et

9 al., 2002), was listed in 2008 as "endangered" under the ESA, and is not currently

10 showing signs of recovery; no harvest is currently allowed. Generally, beluga whales

11 prey on a wide variety of fish, crustaceans, and cephalopods. In Cook Inlet, primary prey

12 species consist of at least three species of Pacific salmon (Chinook, Oncorhynchus

13 tshawytscha; chum, O. keta; and coho, O. kisutch), which have been found in beluga

14 stomachs, however it is likely that sockeye (O. nerka) and pink salmon (O.gorbuscha)

15 are also eaten when they are available (Quakenbush et al., 2015). In addition, eulachon

16 (Thaleichthys pacificus), Pacific cod (Gadus macrocephalus), walleye pollock (Theragra

17 chalcogramma), saffron cod (Eleginus gracilis), starry flounder (Platichthys stellatus)

18 and yellowfin sole (Limanda aspera) have also been found in the stomachs of Cook Inlet

19 belugas. Seven types of invertebrates were found in Cook Inlet beluga stomachs, with the

20 frequency of occurrence in non-empty stomachs being highest for shrimp (39\%),

21 followed by polychaetes and amphipods (Quakenbush et al., 2015). Invertebrates appear

22 to be much less important to Cook Inlet beluga diet compared to the other stocks. 
1 Therefore, analysis of HABs in other beluga stocks would be of interest (Moore et al.,

2 2000).

3 The two belugas sampled from the Eastern Bering stock did not have detectable

4 levels of DA and were not tested for STX. A relatively low percentage of Cook Inlet

5 beluga whales we examined were positive for DA (13\%) and fewer for STX (8\%). In

6 addition, all concentrations of both toxins were low with the highest level of DA at $7 \mathrm{ng} / \mathrm{g}$

7 from stomach contents of one animal and STX at $4 \mathrm{ng} / \mathrm{g}$ feces in another, the only STX

8 positive beluga (Tables 2 and 3). This may be because beluga prey consists of fewer

9 planktivorous fish and invertebrate species. Although DA has been shown to be widely

10 distributed in fish species in California, the non-planktivorous fish species contained

11 lower concentrations of toxin compared to planktivorous species such as anchovies and

12 sardines (Lefebvre et al., 2002a; Lefebvre et al., 2002b). This is similarly true for STX in

13 that PSP toxins can be found in several of the prey species including Pacific cod and

14 chum salmon, but at lower levels. Crabs and polychaetes are known to concentrate STX

15 (Deeds et al., 2008).

17 4.1.4 Harbor porpoises: Harbor porpoises are widespread in the Northern

18 Hemisphere, found in most cool temperate and subpolar waters (Jefferson et al., 1993),

19 including coastal and inland waters, and are seldom found in waters with an annual

20 average temperature above $17^{\circ} \mathrm{C}(\operatorname{Read}, 1999)$. They generally forage on small, pelagic

21 schooling fish in waters less than $200 \mathrm{~m}$ deep (Shelden et al., 2014). Harbor porpoises are

22 not harvested for food in Alaska. In Alaskan waters, harbor porpoise stock structure is

23 unclear, but three stocks are currently recognized for management purposes: Southeast 
1 Alaska, Gulf of Alaska, and Bering Sea (Shelden et al., 2014), all of which belong to the

2 subspecies P.p. yomerina. Harbor porpoises eat a wide variety of fish, cephalopods and

3 benthic invertebrates with the main prey items varying by region and season (Culik,

4 2004; Jefferson et al., 1993; Reyes, 1991). In Cook Inlet, harbor porpoises feed on

5 schooling planktivorous fish such as smelt (Family Osmeridae) and Pacific herring

6 (Clupea pallasii pallasii) (Shelden et al., 2014), which are known to accumulate DA.

7 Harbor porpoise samples were collected primarily from Cook Inlet with one animal each

8 from Prince William Sound and Kachemak Bay. The highest concentration of DA was

$9 \quad 15.3 \mathrm{ng} / \mathrm{g}$, which occurred in the feces of one animal and the intestinal contents of

10 another animal. One of these was pregnant and the fetus also contained DA at $8 \mathrm{ng} / \mathrm{g}$ in

11 its feces documenting maternal transfer of algal toxins. Saxitoxin was not detected in any

12 of the harbor porpoise samples. The higher prevalence of DA is likely a result of a

13 planktivorous fish diet.

154.2 Otariids

16 4.2.1 Northern fur seals: Northern fur seals breed and give birth on the Pribilof

17 Islands of Alaska in the southern Bering Sea during the summer (June-August) and pups

18 remain dependent until mid-November when the rookeries are abandoned for the winter

19 and weaning occurs abruptly. Immature males are harvested for food in summer. In

20 Alaska, the majority of northern fur seals winter in the North Pacific and return to

21 Alaskan waters the following spring. Movements from seals tagged with satellite-linked

22 transmitters indicate that all sex and age classes can migrate thousands of kilometers as

23 far west as Kamchatka and east to the west coast of the USA (Baker, 2007; Lea et al., 
1 2009; Pelland et al., 2014; Ream et al., 2005; Sterling et al., 2014). Newly weaned pups

2 may remain south of the Aleutian chain for two or more years before returning to the

3 Pribilofs to breed. Northern fur seals in Alaska predominantly forage on schooling fish

4 and gonatid squid with walleye pollock representing approximately $40-75 \%$ of the prey

5 observed in scat collections (Ream et al., 2005; Sinclair et al., 1994). Little is known

6 about the recent winter diet since pelagic sealing and the collection of seals for scientific

7 purposes has ceased. Collections made during 1958-1974 in the eastern Bering Sea,

8 however, indicated that in addition to pollock, northern fur seals consumed capelin,

9 Pacific herring, and squid (Perez and Big, 1986). The serum samples for this study were

10 collected from adult female fur seals with young pups. Provisioning pups with milk every

11 few days limits the distance that females can forage to relatively local waters near the

12 Pribilof Islands and may explain the relatively low occurrence of DA and STX (both at

$135 \%$ of the animals tested; Tables 2 and 3 ).

15 4.2.2 Steller sea lions: Steller sea lions range throughout the Pacific Rim from

16 southern California, across the Gulf of Alaska, to Northern Honshu Island in Japan, and

17 north into the Bering Strait (Lander et al., 2009). In Alaska, they are harvested for food

18 and managed as two stocks, the eastern distinct population segment (DPS) and western

19 DPS. From 1980 to 2000 there was a greater than $80 \%$ population decline in the western

20 DPS, which included Russian and Alaskan waters of the Gulf of Alaska, North Pacific

21 Ocean, and Bering Sea, leaving fewer than 55,000 individuals (Lander et al., 2009).

22 Steller sea lions were listed as threatened under the ESA in 1990, and the western portion

23 of the population was reclassified as endangered in 1997. The cause of the decline is 
1 unknown. The population has stabilized in the Gulf of Alaska and the eastern DPS, but

2 continues to decline in the western and central Aleutian Islands. Adult Steller sea lions

3 eat a wide variety of fish, with either walleye pollock or Atka mackerel (Pleurogrammus

4 monopterygius) predominant in most areas. Other prey consists of schooling fish,

5 including Pacific herring and salmon (Oncorhynchus spp.), with smaller numbers of

6 Pacific sand lance (Ammodytes hexapterus), capelin, eulachon, Pacific cod, Pacific hake

7 (Merluccius productus), flatfish, demersal fish, and cephalopods (Merrick et al., 1997).

8 Several of these prey species are planktivorous including herring, juvenile chum salmon,

9 walleye pollock and sand lance.

\section{$114.3 \quad$ Harbor seals}

12 In Alaska, harbor seals are primarily found in coastal waters throughout the Gulf

13 of Alaska, Aleutian Islands, and Southeastern Bering Sea where they are harvested for

14 food (Small et al., 2003). They are found in diverse habitats including glacial and non-

15 glacial areas and are generally non-migratory (Bigg, 1981). Harbor seals mainly forage

16 on fish including Pacific herring, rainbow smelt (Osmerus mordax), salmon

17 (Salmonidae), walleye pollock, Pacific cod, greenling (Hexagrammidae), sculpins

18 (Cottidae), Pacific sand lance, and flatfish (Pleuronectidae) (Pitcher, 1980a, 1980b).

19 Invertebrates such as octopus, squid, and shrimp are also consumed (Pitcher, 1980a,

20 1980b). The importance of these prey items varies by location. In the Bering Sea and

21 Gulf of Alaska, pollock and octopus are the most common prey items, whereas shrimp

22 and capelin are most common in the southeastern Gulf of Alaska (Pitcher, 1980b). No

23 harbor seals tested positive for STX, however six of nine animals tested positive for DA, 
1 although the maximum concentration was low; $8 \mathrm{ng} / \mathrm{g}$ feces (Table 2). Harbor seals had a

2 much higher percentage of individuals that tested positive (67\%) than spotted seals (3\%)

3 even though they consume similar fish species. This could be due to the more southern

4 range of harbor seals compared to the spotted seal's more northerly range in the Bering

5 Sea. Most harbor seals sampled were from the Gulf of Alaska, which has warmer waters

6 and as such are more likely to be exposed to HABs, although no data are available on

$7 \quad \mathrm{HAB}$ or shellfish toxicity for verification. Additionally, the samples sizes tested were

8 vastly different ( $\mathrm{n}=9$ for harbor seals and $\mathrm{n}=158$ for spotted seals) making direct

9 comparisons difficult.

$114.4 \quad$ Ice seals (Ringed, Bearded, Spotted and Ribbon)

12 Ringed, bearded, and spotted seals are sea ice-associated seals that range

13 throughout the Bering, Chukchi, and Beaufort seas in Alaska (Burns, 1970). Of these

14 species, only ringed seals are currently ESA listed. Bearded seals were listed under ESA,

15 but a court overturned the decision, which is being appealed by the National Marine

16 Fisheries Service (NMFS). Ribbon seals are also ice-associated and occur throughout the

17 Bering and Chukchi seas, but are not often found in the Beaufort Sea (Burns, 1981).

18 Although movements in winter months are restricted by sea ice, these seals move widely

19 in spring, summer, and fall (Burns, 1970; Burns, 1981; Crawford et al., 2012; Harwood et

20 al., 2012a; Harwood et al., 2012b; Lowry et al., 2000). Ringed and bearded seals tend to

21 inhabit areas that are seasonally ice covered and are found in heavy pack ice. Spotted

22 and ribbon seals are less ice dependent at certain times of the year and can be found near

23 the ice edge, in the broken pack ice, of the Bering Sea in winter and spring. The 
1 distribution of spotted seals shifts northward and toward the coasts as sea ice recedes in

2 May and June and many spotted seals enter bays and rivers and haul out on sand bars and

3 barrier islands (Burns et al., 1981). The distribution of ribbon seals also shifts northward

4 as sea ice recedes in May and June. When sea ice melts, however, the majority of the

5 ribbon seal population likely becomes pelagic in the North Pacific and the central Bering

6 Sea, although some seals follow receding ice into the Chukchi Sea (Burns et al., 1981).

$7 \quad$ All four species are harvested for food, mostly in spring and fall.

8 The diets of ringed, bearded, spotted, and ribbon seals vary widely. Ringed seals

9 feed mostly in the water column on pelagic and semi-demersal fish (including arctic cod,

10 Boreogadus saida; saffron cod, walleye pollock, and sculpins) and invertebrates

11 (including mysids, amphipods, shrimps and echiurids) (Crawford et al., 2015; Dunbar,

12 1941; Fedoseev, 1965; Johnson et al., 1966; Lowry et al., 1980; McLaren, 1958).

13 Bearded seals feed on a wide variety of benthic invertebrates (including bivalves,

14 gastropods, cephalopods, isopods, amphipods, shrimp, crab, echiurids and polychaetes)

15 and fish (including arctic and saffron cod; sculpins; snailfish (Liparidae); pricklebacks

16 (Stichaeidae); Pacific sandlance, and flatfish) (Antonelis et al., 1994; Burns, 1981;

17 Chapskii, 1938; Crawford et al., 2015; Dunbar, 1941; Quakenbush et al., 2011; Smith,

18 1981). Spotted seals eat mostly pelagic fish including arctic and saffron cod; Pacific

19 herring; and smelt (Bukhtiyarov et al., 1984; Frost and Lowry, 1981; Quakenbush et al.,

20 2009). Ribbon seal diet is less well documented because most have empty stomachs

21 when they are harvested in the late spring. But their diet is most similar to spotted seals

22 and includes fish (arctic and saffron cod and pollock), shrimp (Crangonid and Pandalid 
1 species) and octopus (Dehn et al., 2007; Frost and Lowry, 1980; Quakenbush and Citta,

2 2008).

3 Bearded (25\%) and ribbon seals (24\%) were similar in the percent sampled that

4 contained DA. Fewer ringed seals (17\%) were positive, but a female ringed seal pup had

5 the highest concentration of DA (127 ng/g) of any of the ice seals. Spotted seals were the

6 lowest (3\% positive). Bearded and ringed seals were both 14\% positive for STX and

7 again ringed seals had the higher concentration (172 ng/g feces). Spotted seals were

8 lower at 1\% and STX was not detected in any ribbon seals. We would expect bearded

9 seals, as benthic feeders, to be most vulnerable to STX. We would also expect spotted

10 and ribbon seals, as fish-eaters, to be least vulnerable to STX. The higher values for both

11 DA and STX for ringed seals may be due to some individuals consuming larger volumes

12 of mysids, euphausiids, or amphipods (all of which eat algae and detritus) and may

13 explain their higher exposure to HABs.

\section{$15 \quad 4.5 \quad$ Pacific walrus}

16 Pacific walruses are migratory, following the southern margins of the pack ice

17 from the Bering Sea to the Chukchi Sea in the spring, where foraging is optimal in the

18 relatively shallow shelf waters (Estes and Gilbert, 1978; Fay, 1982; Gilbert, 1989).

19 Walruses are harvested for subsistence and in addition to walrus tissues, clams found in

20 the stomach during butchering are also eaten by harvesters. The Pacific walrus population

21 is currently a candidate species under the ESA due to concern regarding the species'

22 response to changes in summer sea ice habitat (Robards and Garlich-Miller, 2013;

23 USFWS, 2011). Walruses feed primarily on benthic invertebrates including marine 
1 worms (e.g., polychaetes, sipunculids, echiurids priapulids), mollusks (e.g., bivalves and

2 gastropods), and crustaceans (e.g., amphipods, shrimp, crabs) (Born et al., 2003; Bowen

3 and Siniffand, 1999; Dehn et al., 2007; Fay, 1982; Sheffield et al., 2001; Sheffield and

4 Grebmeier, 2009) although fish and other vertebrates (including seals) are also

5 occasionally reported (Fay, 1982; Seymour et al., 2014; Sheffield et al., 2001; Sheffield

6 and Grebmeier, 2009). Walruses are not physiologically adapted for deep diving and

7 concentrate foraging efforts in shallower waters, typically using the sea ice as a resting

8 platform between feeding trips (Fay, 1982). Since 2007, walruses summering in the

9 Chukchi Sea have been hauling out in large numbers at two terrestrial haulout sites on the

10 eastern Chukchi Sea (Icy Cape and Point Lay) beginning in late summer when sea ice

11 over the Continental Shelf disappears (Robards and Garlich-Miller, 2013).

12 Stomach contents from walruses sampled near St. Lawrence Island had the

13 highest measured concentrations of both DA and STX of any species examined in this

14 study (Tables 2 and 3). That $41 \%$ and $28 \%$ of walruses sampled contained elevated

15 concentrations of DA and STX, respectively, is surprising due to the sampling location.

16 These walruses were sampled in the northern Bering Sea during May, as they were

17 moving northward with the receding sea ice (Fay, 1982). Water temperatures with sea ice

18 present are not considered favorable to support HABs, although the DA and STX could

19 have come from invertebrates eaten farther south. The elevated toxin concentrations in

20 walruses suggest that DA and STX producing phytoplankton are well established in

21 seasonally ice covered waters to accumulate in clams within the foraging range of

22 walruses. That the highest concentrations of both DA and STX in this study came from

23 walruses and that the walrus with the highest concentration of STX also had relatively 
1 high DA is cause for continued monitoring and investigation. The DA concentrations

2 detected in walruses are similar to those detected in California sea lions suffering from

3 DA toxicosis, although hunters did not report abnormal behavior in any of the sampled

4 walruses (Figure 2; (Lefebvre et al., 1999; Scholin et al., 2000).

5 Walruses and bearded seals are typically benthic feeders with overlapping ranges,

6 but the percent positive and maximum concentration for both DA and STX was higher

7 for walruses than bearded seals. This could be because bearded seals are more generalist

8 foragers than walruses.

9

$10 \quad 4.6 \quad$ Sea otters

11 Three stocks of northern sea otters are recognized in Alaska: southeast,

12 southcentral, and southwest (Gorbics and Bodkin, 2001). The southeast and southcentral

13 stocks are considered to be increasing. The southwest stock, however, was listed as

14 threatened under the ESA in 2005, but is currently believed to have stabilized (USFWS

15 2014).

16 The primary prey of sea otters in the Gulf of Alaska (Southeast Alaska, Prince

17 William Sound, Kachemak Bay and Kodiak Island) are clams, such as butter clams

18 (Saxidomus giganteus) (Calkins, 1978; Doroff and Bodkin, 1994; Doroff and Degange,

19 1994; Hoyt et al., 2014; Kvitek et al., 1993). In contrast, the diet in the Aleutian Islands is

20 dominated by sea urchins and a variety of finfish, including those in the families of

21 Hexagrammidae, Gadidae, Cottidae, Cyclopteridae, and Scorpaenidae (Estes et al., 1982;

22 Kenyon, 1969). The majority of the sea otter carcasses recovered and sampled for this 
1 study were from the northern Gulf of Alaska (i.e. Kachemak Bay) where clams are an

2 important prey item (Doroff et al., 2012; Newsome et al., 2015).

3 Given that clams are the predominant prey items for sea otters in Alaska, the

4 percentage of sea otters containing detectable concentrations of DA and STX were lower

5 than expected (Tables 2 and 3) and in the case of STX, may be due to avoidance

6 behaviors. Although sea otters are not immune to PSP toxins, they can detect and avoid

7 lethal amounts of toxic prey (Kvitek and Bretz, 2004; Kvitek, 1991). However, acute

8 toxicosis from STX may have contributed to at least two sea otters being struck and

9 killed by boats in November 2009 in the Kodiak boat harbor (Gill et al. in prep). Urine

10 from these two otters were included in this study and had the highest concentrations of

11 STX (45 and >100 ng/g) for all otters tested. Their behavior prior to being hit by the

12 boats was suggestive of intoxication as they were lethargic and non-reactive at the

13 surface of the water.

14 Additionally, between May 12-28, 2011 sea otters ( $\mathrm{n}=21)$ were live-captured

15 around Kuiu Island in Southeast Alaska (Figure 1). Urine was collected and they were

16 implanted with VHF transmitters and released (Hoyt et al., 2014). Twenty of these otters

17 contained detectable concentrations of STX (3.0-28.4 ng/ml urine). During capture and

18 handling, none of these animals exhibited any clinical signs (i.e. paralysis, difficulty

19 breathing) associated with STX toxicity. After being released they were relocated and

20 feeding was observed between August 2011 and May 2013. Tagged sea otters consumed

21 a total of 32 unique prey types (Hoyt et al., 2014). In terms of biomass, the three most

22 common prey items were clams (primarily Saxidomus giganteus) followed by green

23 urchins (Strongylocentrotus droebachiensis) and Dungeness crab (Metacarcinus 
1 magister). Continuing to track DA and STX concentrations in sea otters will be important

2 in understanding threats to their populations especially in the ESA-listed stock. As otters

3 are a nearshore, highly visible species that do haul out on land in some human inhabited

4 Alaskan locations, it may be prudent to set up protocols for documenting and reporting

5 signs of HAB-related toxicosis.

6

$7 \quad 4.7 \quad$ Toxic Exposure Levels and Data Limitations

8 An understanding of how the concentrations reported here relate to those known

9 to cause clinical signs of toxicity (behavioral neuroexcitotoxicity for DA and paralysis for

10 STX) in mammals from other regions is needed in order to assess health risks to Alaskan

11 marine mammals. Data on STX concentrations quantified in marine mammals

12 experiencing toxicosis are lacking, however, data for DA concentrations are prevalent

13 due to the regular occurrence of DA toxicosis in California sea lions along the central

14 California coast, USA. Figure 2 compares concentrations of DA quantified in feces and

15 urine of ten acutely exposed California sea lions exhibiting seizures with concentrations

16 quantified in Alaskan species. These data suggest that Alaskan marine mammals may

17 already be near toxic exposures particularly in humpback and bowhead whales, ringed,

18 bearded and spotted seals, Pacific walruses and sea otters (Figure 2A \& B).

19 A major limitation in the assessment of health risks is that toxin concentrations in

20 marine mammal samples are not directly related to the magnitude of an animal's

21 exposure. For example, not all California sea lions with acute behavioral signs of toxicity

22 (e.g., seizures) have high concentrations of DA in feces and urine because elimination

23 rates are rapid (Lefebvre et al., 1999)(Figure 2). Passage rates for captive sea lions fed 
1 Pacific herring averaged less than 5 hours (Helm, 1984) and laboratory studies have

2 reported 99\% of algal toxin is eliminated through urine within 24 hours of dosing (Suzuki

3 and Hierlihy, 1993). Therefore, the concentrations presented here provide proof of

4 exposure risk and evidence for potential neurotoxic impacts to several marine mammal

5 species in Alaska.

6

7 5. Conclusions

8 Our results demonstrate that the algal toxins DA and STX are present in Alaskan

9 Subarctic and Arctic ecosystems and have the potential to affect most marine mammal

10 species in USA waters farther north than expected. Given the current trend of decreasing

11 sea ice and warming ocean waters that will extend the open water season favorable to

12 HABs, the prevalence and concentrations of DA and STX documented in this study are

13 expected to increase creating a greater risk to marine mammals. Clinical signs of

14 neurotoxicity were not confirmed in the present study, however many of the animals were

15 dead when sampled. Additionally, toxin effects could contribute to an increase in ship

16 strikes for large cetaceans and increased vulnerability to subsistence harvested seals,

17 walruses and whales, both of which would be difficult to detect due to concurrent

18 increases in ship traffic and changes in ice and weather patterns that affect hunting. Sea

19 lions along the central California coast provide a cautionary example of increasing HAB

20 impacts on marine mammal health. This threat to marine mammals was first recognized

21 in 1998, and now has a major impact on sea lions annually. Recent studies have

22 suggested that HABs are also affecting large cetaceans in southern latitudes such as the

23 Minke whale (Balaenoptera acutorostrata) (Fire et al., 2010). This study documents the 
1 presence of $\mathrm{HAB}$ toxins in top predators from southeast Alaska to the Arctic Ocean

2 revealing a potentially growing exposure risk to northern marine mammal populations.

3 Unless unknown factors inhibit HABs in northern waters, warming water temperatures

4 and increased light availability due to loss of sea ice are likely to support more blooms

5 increasing toxin concentrations and the health risks they present for northern marine

6 mammal species as they have for southern species.

\section{Acknowledgements:}

10 Without the efforts and support of the coastal communities of northern and

11 western Alaska allowing us to examine their marine mammals, we would not have the

12 information presented in this manuscript regarding Arctic species. We greatly appreciate

13 the willingness of subsistence hunters to share their harvested seals, walrus, bowhead and

14 belugas for research. We thank the whaling captains of Barrow, Alaska and the Alaska

15 Eskimo Whaling Commission for allowing the sampling of subsistence harvested

16 bowhead whales. Samples were collected under NMFS Permit 17350-00 issued to the

17 North Slope Borough Department of Wildlife Management. We would like to thank the

18 Native Villages of Gambell and Savoonga and all of the subsistence hunters who donated

19 walrus samples, and the subsistence hunters and Tribal government of St. Paul Island for

20 their assistance collecting Northern fur seal samples. We would also like to thank Mark

21 Nelson, Louise Foster, Sheena Anningayou, Harold Kiyuklook, and Alaska Department

22 of Fish and Game (ADF\&G) college interns for their help with sample collection and

23 processing. We would like to thank the volunteer Alaska Marine Mammal Stranding 
1 Network and the Alaska SeaLife Center for helping with sample collection. Additionally,

2 we express gratitude to Kristin Worman at the US Fish and Wildlife Service (USFWS)

3 for helping with sea otter samples. Sea otter samples were collected under MMPA permit

4 No. MA041309-5 issued to USFWS Marine Mammals Management office. Other

5 stranded marine mammal samples were collected under NMFS permits 932-1489 and

6 932-1905 and some of the work was funded through John H. Prescott Marine Mammal

7 Rescue Assistance grants NA09NMF4390236 and NA12NMF4390162. Sample

8 collection was funded by the USFWS, ADF\&G and NOAA's National Marine Fisheries

9 Service (NMFS). Samples contributed by ADF\&G were collected and analyzed under

10 NMFS research permit \#s 358-1787, 15324 and 10091 and USFWS collection letters

11 issued to ADF\&G. Samples of adult female northern fur seals were collected under

12 authorization of NMFS permit \#14327 issued to the Marine Mammal Laboratory. Data

13 for intoxicated California sea lions shown in Figure 2 came from the US West Coast

14 Wildlife Algal Toxin Research and Response Network (WARRN-West) and the Marine

15 Mammal Center databases. This project was funded by the North Pacific Research Board

16 (NPRB project \#1113, publication \#575). Additional support for research staff and toxin

17 analyses came from grants from the National Institute of Health (NIH) R01 ES021930

18 and the National Science Foundation (NSF) OCE-1314088. We thank Dr. Linda Rhodes

19 and Dr. Walt Dickhoff of the NWFSC, Dr. Teri Rowles of the Office of Protected

20 Resources (NOAA) and Dr. Peter Boveng of the Polar Ecosystems Program

21 (NOAA/MML) for careful review of the manuscript. Special thanks goes to Su Kim and

22 Damon Holzer of the NWFSC for help creating the Figure 1 map. 
The findings and conclusions in this article are those of the authors and do not necessarily represent the views of the U.S. Fish and Wildlife Service and NOAA Fisheries. Mention of trade names or commercial products is solely for providing specific

4 information and does not imply recommendation or endorsement.

\section{References:}

Antonelis, G.A., Melin, S.R., Bukhtiyarov, Y.A., 1994. Early spring feeding habits of bearded seals (Erignathus barbatus) in the Central Bering Sea, 1981. Arctic 47(1), 74-79.

10 Baker, C.S., Herman, L.M., Perry, A., Lawton, W.S., Straley, J.M., Wolman, A.A.,

11 Kaufman, G.D., Winn, H.E., Hall, J.D., Reinke, J.M., Ostman, J., 1986. Migratory

12 movement and population structure of humpback whales (Megaptera novaeangliae) in the central and eastern North Pacific. Mar Ecol Prog Ser 31, 105-119. Baker, J.D., 2007. Post-weaning migration of northern fur seal Callorhinus ursinus pups from the Pribilof Islands, Alaska. Mar Ecol Prog Ser 341, 243-255. Bargu, S., Powell, C.L., Coale, S.L., Busman, M., Doucette, G.J., Silver, M.W., 2002. Krill: A potential vector for domoic acid in marine food webs. Marine Ecology-Progress

18 Series 237, 209-216.

19 Bargu, S., Silver, M., Goldstein, T., Roberts, K., Gulland, F., 2010. Complexity of patterns, climate events, and toxic blooms. Marine Ecology-Progress Series 418, 213-222.

Berman, F.W., LePage, K.T., Murray, T.F., 2002. Domoic acid neurotoxicity in cultured cerebellar granule neurons is controlled preferentially by the NMDA receptor $\mathrm{Ca}(2+)$ influx pathway. Brain Res 924(1), 20-29.

Berman, F.W., Murray, T.F., 1997. Domoic acid neurotoxicity in cultured cerebellar granule neurons is mediated predominantly by NMDA receptors that are activated as a consequence of excitatory amino acid release. J Neurochem 69(2), 693-703. Bigg, M.A., 1981. Harbour Seals Phoca vitulina Linnaeus, 1758 and Phoca largha Pallas, 1811. Academic Press, New York, NY.

Born, E.W., Rysgaard, S., Ehlme', G., Sejr, M., Acquarone, M., Levermann, N., 2003. Underwater observations of foraging free-living Atlantic walruses (Odobenus rosmarus rosmarus) and estimates of their food consumption. Polar Biol 26, 348357.

Bowen, D., Siniffand, D.B., 1999. Distribution, population biology, and feeding ecology of marine mammals, In: J.E., R., Rommel, S.A. (Eds.), Biology of Marine Mammals. Smithsonian Institution Press, Washington, DC, pp. 423-484 Brodie, E.C., Gulland, F.M.D., Greig, D.J., Hunter, M., Jaakola, J., St Leger, J., Leighfield, T.A., Van Dolah, F.M., 2006. Domoic acid causes reproductive failure in california sea lions (Zalophus californianus). Mar Mammal Sci 22(3), 700-707. 
Bukhtiyarov, Y.A., Frost, K.J., Lowry, L.F., 1984. New information on foods of the spotted seal, Phoca largha, in the Bering sea in Spring, In: Fay, F.H., Fedoseev, G.A. (Eds.), Soviet-America cooperative research on marine mammals, U.S. Department of Commerce, pp. 55-59.

Burek, K.A., Gulland, F.M., O'Hara, T.M., 2008. Effects of climate change on Arctic marine mammal health. Ecol Appl 18(2 Suppl), S126-134.

Burns, J.J., 1970. Remarks on the distribution and natural history of pagophilic pinnipeds in the Bering and Chukchi seas. Journal of Mammalogy 51, 445-454. Burns, J.J., 1981. Ribbon seal Phoca fasciata Zimmermann, 1783. Academic Press, New York, NY. Burns, J.J., Shapiro, L.H., Fay, F.H., 1981. Ice as marine mammal habitat in the Bering Sea. U.S. Department of Commerce, NOAA, U.S. Department of Interior, Office of Marine Pollution Assessment, and Bureau of Land Management, Washington, D.C. Bursa, A., 1963. Phytoplankton in coastal waters of the Arctic Ocean at Point Barrow, Alaska. Arctic 16, 239-262. Calkins, D.G., 1978. Feeding-Behavior and Major Prey Species of Sea Otter, EnhydraLutris, in Montague Strait, Prince-William-Sound, Alaska. Fish B-Noaa 76(1), 125131.

Chapskii, K.K., 1938. The Bearded Seal (Erignathus barbatus Fabr.) of the Kara and Barents Sea. Trudy Arktichoskogo Instituta 123, 7-70. Cook, P.F., Reichmuth, C., Rouse, A.A., Libby, L.A., Dennison, S.E., Carmichael, O.T., Kruse-Elliott, K.T., Bloom, J., Singh, B., Fravel, V.A., Barbosa, L., Stuppino, J.J., Van Bonn, W.G., Gulland, F.M., Ranganath, C., 2015. Algal toxin impairs sea lion memory and hippocampal connectivity, with implications for strandings. Science 350(6267), 1545-1547.

Costa, P.R., Baugh, K.A., Wright, B., Ralonde, R., Nance, S.L., Tatarenkova, N., Etheridge, S.M., Lefebvre, K.A., 2009. Comparative determination of paralytic shellfish toxins (PSTs) using five different toxin detection methods in shellfish species collected in the Aleutian Islands, Alaska. Toxicon 54(3), 313-320.

Costas, E., Lopez-Rodas, V., 1998. Paralytic phycotoxins in monk seal mass mortality. Veterinary Record 142(23), 643-644.

Crawford, J.A., Frost, K.J., Quakenbush, L.T., Whiting, A., 2012. Different habitat use strategies by subadult and adult ringed seals (Phoca hispida) in the Bering and Chukchi seas. Polar Biol 35(2), 241-255.

Crawford, J.A., Quakenbush, L.T., Citta, J.J., 2015. A comparison of ringed and bearded seal diet, condition and productivity between historical (1975-1984) and recent (2003-2012) periods in the Alaskan Bering and Chukchi seas. Progress in Oceanography.

Culik, B.M., 2004. Review of small cetaceans. Distribution, Behaviour, Migration and Threats, Regional Seas Reports and Studies.

Cusick, K.D., Sayler, G.S., 2013. An overview on the marine neurotoxin, saxitoxin: genetics, molecular targets, methods of detection and ecological functions. Mar Drugs 11(4), 991-1018.

Deeds, J.R., Landsberg, J.H., Etheridge, S.M., Pitcher, G.C., Longan, S.W., 2008. Nontraditional vectors for paralytic shellfish poisoning. Marine Drugs 6(2), 308-348. 
Degange, A.R., Vacca, M.M., 1989. Sea Otter Mortality at Kodiak Island, Alaska, during

2 Summer 1987. Journal of Mammalogy 70(4), 836-838.

3 Dehn, L.A., Sheffield, G.G., Follmann, E.H., Duffy, L.K., Thomas, D.L., O'Hara, T.M.,

4 2007. Feeding ecology of phocid seals and some walruses in the Alaskan and

5 Canadian Arctic as determined by stomach contents and stable isotope analysis.

6 Polar Biol 30(2), 167-181. otter (Enhydra lutris kenyoni) diet in Kachemak Bay, Alaska (2008-2010). IUCN Otter Spec Group Bull 29, 15-23.

Doroff, A.M., Bodkin, J.L., 1994. Sea otter foraging behavior and hydrocarbon levels in prey. Academic Press, San Diego, CA.

Doroff, A.M., Degange, A.R., 1994. Sea Otter, Enhydra-Lutris, Prey Composition and Foraging Success in the Northern Kodiak Archipelago. Fish B-Noaa 92(4), 704-710. Doucette, G.J., Turner, J.T., Powell, C.L., Keafer, B.A., Anderson, D.M., 2005. Trophic accumulation of PSP toxins in zooplankton during Alexandrium fundyense blooms in Casco Bay, Gulf of Maine, April-June 1998. I. Toxin levels in A-fundyense and zooplankton size fractions. Deep-Sea Research Part Ii-Topical Studies in Oceanography 52(19-21), 2764-2783.

Dunbar, M.J., 1941. On the food of seals in the Canadian eastern Arctic. Canadian Journal of Research 19, 150-155.

Estes, J.A., Gilbert, J.R., 1978. Evaluation of an Aerial Survey of Pacific Walruses (Odobenus-Rosmarus Divergens). J Fish Res Board Can 35(8), 1130-1140.

Estes, J.A., Jameson, R.J., Rhode, E.B., 1982. Activity and Prey Election in the Sea Otter - Influence of Population Status on Community Structure. Am Nat 120(2), 242-258. Fay, F.H., 1982. Ecology and biology of the Pacific walrus, Odobenus rosmarus divergens illiger, U.S. Fish and Wildlife Service, North American Fauna, Washington, D. C., p. 279.

Fedoseev, G.A., 1965. Food of the ringed seal. Izvestiya TINRO 59, 216-223. Fire, S.E., Wang, Z., Berman, M., Langlois, G.W., Morton, S.L., Sekula-Wood, E., Benitez-Nelson, C.R., 2010. Trophic Transfer of the Harmful Algal Toxin Domoic Acid as a Cause of Death in a Minke Whale (Balaenoptera acutorostrata) Stranding in Southern California. Aquatic Mammals 36(4), 342-350.

Flewelling, L.J., Naar, J.P., Abbott, J.P., Baden, D.G., Barros, N.B., Bossart, G.D., Bottein, M.Y., Hammond, D.G., Haubold, E.M., Heil, C.A., Henry, M.S., Jacocks, H.M., Leighfield, T.A., Pierce, R.H., Pitchford, T.D., Rommel, S.A., Scott, P.S., Steidinger, K.A., Truby, E.W., Van Dolah, F.M., Landsberg, J.H., 2005. Brevetoxicosis: red tides and marine mammal mortalities. Nature 435(7043), 755-756.

Frame, E.R., Lefebvre, K.A., 2012. ELISA methods for domoic acid quantification in multiple marine mammal species and sample matrices Northwest Fisheries Science Center, NOAA Fisheries, Seattle, WA.

Frost, K.J., Lowry, L.F., 1980. Feeding of Ribbon Seals (Phoca-Fasciata) in the Bering Sea in Spring. Can J Zool 58(9), 1601-1607.

Frost, K.J., Lowry, L.F., 1981. Ringed, Baikal and Caspian seals-Phoca hispida, Phoca sibirica, and Phoca caspica. Academic Press, New York, NY. 
George, J.C.C., Zeh, J., Suydam, R., Clark, C., 2004. Abundance and population trend (1978-2001) of western Arctic bowhead whales surveyed near Barrow, Alaska. Mar Mammal Sci 20(4), 755-773.

Geraci, J.J., Anderson, D.M., Timperi, R.J., Staubin, D.J., Early, G.A., Prescott, J.H., Mayo, C.A., 1989. Humpback whales (Megaptera novaeangliae) fatally poisoned by dinoflagellate toxin. Can. J. Fish. Aquat. Sci. 46(11), 1895-1898. Gerber, L.R., Keller, A.C., DeMaster, D.P., 2007. Ten thousand and increasing: Is the western Arctic population of bowhead whale endangered? Biological Conservation 137(4), 577-583.

Gessner, B.D., Middaugh, J.P., 1995. Paralytic shellfish poisoning in Alaska: a 20-year retrospective analysis. Am J Epidemiol 141(8), 766-770.

Gessner, B.D., Middaugh, J.P., Doucette, G.J., 1997. Paralytic shellfish poisoning in Kodiak, Alaska. West J Med 167(5), 351-353.

Gessner, B.D., Schloss, M., 1996. A population-based study of paralytic shell fish poisoning in Alaska. Alaska Medicine 38(2), 54-58.

Gilbert, J.R., 1989. Aerial Census of Pacific Walruses in the Chukchi Sea, 1985. Mar Mammal Sci 5(1), 17-28.

Givens, G.H.G., Edmonson, S.L., George, J.C., Suydam, R., Charif, R.A., Rahaman, A., Hawthorne, D., Tudor, B., De Long, R.A., Clark, C.W., 2013. Estimate of 2011 Abundance of the Bering-Chukchi-Beaufort Seas Bowhead Whale Population, Annual Report to the Scientific Committee of the International Whaling Commission, Colorado State University, Dept. of Statistics, Alaska, p. 30.

Goldstein, T., Mazet, J.A., Zabka, T.S., Langlois, G., Colegrove, K.M., Silver, M., Bargu, S., Van Dolah, F., Leighfield, T., Conrad, P.A., Barakos, J., Williams, D.C., Dennison, S., Haulena, M., Gulland, F.M., 2008. Novel symptomatology and changing epidemiology of domoic acid toxicosis in California sea lions (Zalophus californianus): an increasing risk to marine mammal health. Proc Biol Sci 275(1632), 267-276. Gorbics, C.S., Bodkin, J.L., 2001. Stock structure of sea otters (Enhydra lutris kenyoni) in Alaska. Mar Mammal Sci 17(3), 632-647. Gulland, F., 2000. Domoic acid toxicity in California sea lions (Zalophus californianus) stranded along the central california coast, may-october 1998. Report to the National Marine Fisheries Service Working group on unusual marine mammal Mortality Events., In: U.S. Department of Commerce, N.t.m. (Ed.). Silver Spring, Maryland, p. 45p. Gulland, F.M., Haulena, M., Fauquier, D., Langlois, G., Lander, M.E., Zabka, T., Duerr, R., 2002. Domoic acid toxicity in Californian sea lions (Zalophus californianus): clinical signs, treatment and survival. Vet Rec 150(15), 475-480. Gulland, F.M.D., Hall, A.J., 2007. Is marine mammal health deteriorating? Trends in the global reporting of marine mammal disease. Ecohealth 4(2), 135-150. Hallegraeff, G.M., 1998. Transport of toxic dinoflagellates via ships' ballast water: Bioeconomic risk assessment and efficacy of possible ballast water management strategies. Mar Ecol Prog Ser 168(0), 297-309. Harwood, L.A., Smith, T.G., Auld, J.C., 2012a. Fall Migration of Ringed Seals (Phoca hispida) through the Beaufort and Chukchi Seas, 2001-02. Arctic 65(1), 35-44. 
Harwood, L.A., Smith, T.G., Melling, H., Alikamik, J., Kingsley, M.C.S., 2012b. Ringed Seals and Sea Ice in Canada's Western Arctic: Harvest-Based Monitoring 1992-2011. Arctic 65(4), 377-390.

Helm, R.C., 1984. Rate of digestion in three species of pinnipeds. Canadian Journal of Zoology 62(9), 1751-1756.

Hoyt, Z.N., Eckert, G., Gill, V.A., Rice, A., 2014. Sea otter recolonization and interactions with commercially important macroinvertebrates in southeast Alaska, North Pacific Research Board Final Report, Anchorage, AK, p. 82.

Jefferson, T.A., Leatherwood, S., Webber, W.A., 1993. FAO Species identification guide. UNEP/FAO, Rome. Johnson, M.L., Fiscus, C.H., Ostenson, B.T., Barbour, M.L., 1966. Marine mammals. U.S. Atomic Energy Commission, Oak Ridge, TN. Kenyon, K.W., 1969. The sea otter in the eastern Pacific Ocean. North American Fauna 68, 352.

Kvitek, R., Bretz, C., 2004. Harmful algal bloom toxins protect bivalve populations from sea otter predation. Mar Ecol Prog Ser 271, 233-243.

Kvitek, R.G., 1991. Paralytic shellfish toxins sequestered by bivalves as a defense against siphon-nipping fish. Marine biology 111(3), 369-374.

Kvitek, R.G., Bowlby, C.E., Staedler, M., 1993. Diet and Foraging Behavior of Sea Otters in Southeast Alaska. Mar Mammal Sci 9(2), 168-181.

Lander, M.E., Loughlin, T.R., Logsdon, M.G., VanBlaricom, G.R., Fadely, B.S., Fritz, L.W., 2009. Regional differences in the spatial and temporal heterogeneity of oceanographic habitat used by Steller sea lions. Ecol Appl 19(6), 1645-1659. Landsberg, J.H., Lefebvre, K.A., Flewelling, L.J., 2014. Effects of Toxic Microalgae on Marine Organisms, In: Rossini, G.P. (Ed.), Toxins and Biologically Active Compounds from Microalgae. CRC Press, Boca Raton, pp. 379-449.

Lea, M.A., Johnson, D., Ream, R., Sterling, J., Melin, S., Gelatt, T., 2009. Extreme weather events influence dispersal of naive northern fur seals. Biology Letters 5(2), 252-257.

Lefebvre, K.A., Bargu, S., Kieckhefer, T., Silver, M.W., 2002a. From sanddabs to blue whales: the pervasiveness of domoic acid. Toxicon 40(7), 971-977.

Lefebvre, K.A., Powell, C.L., Busman, M., Doucette, C.J., Moeller, P.D.R., Sliver, J.B., Miller, P.E., Hughes, M.P., Singaram, S., Silver, M.W., Tjeerdema, R.S., 1999. Detection of domoic acid in northern anchovies and California sea lions associated with an unusual mortality event. Natural Toxins 7(3), 85-92.

Lefebvre, K.A., Robertson, A., Frame, E.R., Colegrove, C.M., Nance, S., Baugh, K.A., Wiedenhoft, A., Gulland, F.M.D., 2010. Clinical signs and histopathology associated with domoic acid poisoning in northern fur seals (Callorhinus ursinus) and comparison of toxin detection methods. Harmful Algae 9(4), 374-383. Lefebvre, K.A., Silver, M.W., Coale, S.L., Tjeerdema, R.S., 2002b. Domoic acid in planktivorous fish in relation to toxic Pseudo-nitzschia cell densities. Marine biology 140(3), 625-631.

Lewitus, A., Horner, R.A., Caron, D.A., Garcia-Mendoza, E., Hickey, B.M., Hunter, M., Huppert, D.D., Kudela, R.M., Langlois, G., Largier, J.L., 2012. Harmful algal blooms along the North American west coast region: History, trends, causes, and impacts. Harmful Algae 19, 133-159. 
Lowry, L.F., Frost, K.J., Burkonov, V.N., Simpkins, M.A., Davis, R., DeMaster, D.P., Suydam, R., Springer, A., 2000. Habitat use and habitat selection by spotted seals (Phoca largha) in the Bering Sea. Canadian Journal of Zoology 78, 1959-1971. Lowry, L.F., Frost, K.J., Burns, J.J., 1980. Variability in the diet of ringed seals, Phoca hispida, in Alaska. Canadian Journal of Fisheries and Aquatic Sciences 37, 22542261.

Maucher, J.M., Ramsdell, J.S., 2005. Domoic acid transfer to milk: Evaluation of a potential route of neonatal exposure. Environmental Health Perspectives 113(4), 461-464. Maucher, J.M., Ramsdell, J.S., 2007. Maternal-fetal transfer of domoic acid in rats at two gestational time points. Environmental Health Perspectives 115(12), 17431746.

McLaren, I.A., 1958. The Biology of the Ringed Seal (Phoca hispida Schreber) in the Eastern Canadian Arctic. Bulletin Fisheries Research Board of Canada 118, 97. Merrick, R.L., Chumbley, M.K., Byrd, G.V., 1997. Diet Diversity of Steller Sea Lions (Eumetopias jubatus) and their Population Decline in Alaska: a Potential Relationship. Canadian Journal of Fisheries and Aquatic Sciences 54, 1342-1348. Moore, S.E., George, J.C., Sheffield, G., Bacon, J., Ashjian, C.J., 2010. Bowhead Whale Distribution and Feeding near Barrow, Alaska, in Late Summer 2005-06. Arctic 63(2), 195-205.

Moore, S.E., Shelden, K.E., Litzky, L.K., Mahoney, B.A., Rugh, D.J., 2000. Beluga, Delphinapterus leucas, habitat associations in Cook Inlet, Alaska. Marine Fisheries Review 62(3), 60-80.

Moore, S.K., Trainer, V.L., Mantua, N.J., Parker, M.S., Laws, E.A., Backer, L.C., Fleming, L.E., 2008. Impacts of climate variability and future climate change on harmful algal blooms and human health. Environ Health 7 Suppl 2, S4. Newsome, S.D., Tinker, M.T., Gill, V.A., Hoyt, Z.N., Doroff, A., Nichol, L., Bodkin, J.L., 2015. The interaction of intraspecific competition and habitat on individual diet specialization: a near range-wide examination of sea otters. Oecologia 178(1), 4559.

O'Corry-Crowe, G.M., Dizon, A.E., Suydam, R., Lowry, L.F., 2002. Molecular Genetics Studies of Population Structure and Movement Patterns in a Migratory Species: The Beluga Whale, Delphinapterus leucas, in the Western Nearctic, In: Pfeiffer, C.J. (Ed.), Molecular and Cell Biology of Marine Mammals. Krieger Publishing Company, Malabar, Florida. Pelland, N.A., Sterling, J.T., Lea, M.A., Bond, N.A., Ream, R.R., Lee, C.M., Eriksen, C.C., 2014. Fortuitous Encounters between Seagliders and Adult Female Northern Fur Seals (Callorhinus ursinus) off the Washington (USA) Coast: Upper Ocean Variability and Links to Top Predator Behavior. Plos One 9(8).

Perez, M.A., Big, M.A., 1986. Diet of northern fur seals, Calorhinus ursinus, off western North America. Fish B-Noaa 84, 957-971.

Perl, T.M., Bedard, L., Kosatsky, T., Hockin, J.C., Todd, E.C., Remis, R.S., 1990. An outbreak of toxic encephalopathy caused by eating mussels contaminated with domoic acid. N Engl J Med 322(25), 1775-1780.

Pitcher, K.W., 1980a. Food of the Harbor Seal, Phoca-Vitulina-Richardsi, in the Gulf of Alaska. Fish B-Noaa 78(2), 544-549. 
Pitcher, K.W., 1980b. Stomach Contents and Feces as Indicators of Harbor Seal,

2 Phoca-Vitulina, Foods in the Gulf of Alaska. Fish B-Noaa 78(3), 797-798.

3 Quakenbush, L.T., Citta, J.J., 2008. Biology of the ribbon seal in Alaska, Report to

4 National Marine Fisheries Service, p. 46.

5 Quakenbush, L.T., Citta, J.J., Crawford, J.A., 2009. Biology of the spotted seal (Phoca

6 largha) in Alaska from 1962 to 2008, Preliminary report to the National Marine

7 Fisheries Service, p. 66.

8 Quakenbush, L.T., Citta, J.J., Crawford, J.A., 2011. Biology of the Bearded Seal

9 (Erignathus barbatus) in Alaska from 1962 to 2009, Preliminary report to National

10 Marine Fisheries Service, p. 71.

11 Quakenbush, L.T., Suydam, R.S., Bryan, A.L., Lowry, L.F., Frost, K.J., Mahoney, B.A., 2015. Diet of beluga whales, Delphinapterus leucas, in Alaska from stomach contents, March-November. Marine Fisheries Review 77(1), 70-84.

RaLonde, R., Wright, B.A., 2011. Using Blue Mussels as an Indicator Species for Testing Domoic Acid Toxicity in Subsistance Bivalve Harvest, NPRB Final Report. North Pacific Research Board, Anchorage, AK.

Ramsdell, J.S., Zabka, T.S., 2008. In utero domoic acid toxicity: A fetal basis to adult disease in the california sea lion (Zalophus californianus). Marine Drugs 6(2), 262290.

Read, A.J., 1999. Harbour porpoise - Phocoena phocoena (Linnaeus, 1758), Handbook of Marine Mammals: The second book of dolphins and porpoises, pp. 323-356.

Ream, R.R., Sterling, J.T., Loughlin, T.R., 2005. Oceanographic features related to northern fur seal migratory movements. Deep-Sea Research Part Ii-Topical Studies in Oceanography 52(5-6), 823-843.

Reeves, R., Rosa, C., George, J.C., Sheffield, G., Moore, M., 2012. Implications of Arctic industrial growth and strategies to mitigate future vessel and fishing gear impacts on bowhead whales. Marine Policy 36, 454-462.

Reyes, R.C., 1991. The conservation of small cetaceans: a review, Report prepared for the Secretariat of the Convention on the Conservation of Migratory Species of Wild Animals. Robards, M., Garlich-Miller, J., 2013. Workshop on assessing Pacific walrus population attributes from coastal haul-outs, In: Service, U.S.F.a.W. (Ed.), Marine Mammals Management, Anchorage, Alaska.

Rust, L., Gulland, F., Frame, E., Lefebvre, K., 2014. Domoic acid in milk of free living California marine mammals indicates lactational exposure occurs. Mar Mammal Sci 30(3), 1272-1278.

Scholin, C.A., Gulland, F., Doucette, G.J., Benson, S., Busman, M., Chavez, F.P., Cordaro, J., DeLong, R., De Vogelaere, A., Harvey, J., Haulena, M., Lefebvre, K., Lipscomb, T., Loscutoff, S., Lowenstine, L.J., Marin, R., 3rd, Miller, P.E., McLellan, W.A., Moeller, P.D., Powell, C.L., Rowles, T., Silvagni, P., Silver, M., Spraker, T., Trainer, V., Van Dolah, F.M., 2000. Mortality of sea lions along the central California coast linked to a toxic diatom bloom. Nature 403(6765), 80-84.

Seymour, J., Horstmann-Dehn, L., Wooller, M.J., 2014. Proportion of higher trophiclevel prey in the diet of Pacific walruses (Odobenus rosmarus divergens). Polar Biol 37(7), 941-952. 
Sheffield, G., Fay, F.H., Feder, H., Kelly, B.P., 2001. Laboratory digestion of prey and interpretation of walrus stomach contents. Mar Mammal Sci 17(2), 310-330. Sheffield, G., Grebmeier, J.M., 2009. Pacific walrus (Odobenus rosmarus divergens): Differential prey digestion and diet. Mar Mammal Sci 25(4), 761-777.

Shelden, K.E.W., Agler, B.A., Brueggeman, J.J., Cornick, I.A., Speckman, S.G., Prevelramos, A., 2014. Harbor porpoise, Phocoena phocoena vomerina, in Cook Inlet, Alaska. Mar. Fish. Rev. 76, 22-50.

Sinclair, E., Loughlin, T., Pearcy, W., 1994. Prey Selection by Northern Fur Seals

9 (Callorhinus-Ursinus) in the Eastern Bering Sea. Fish B-Noaa 92(1), 144-156.

10 Small, R.J., Pendleton, G.W., Pitcher, K.W., 2003. Trends in abundance of Alaska

harbor seals, 1983-2001. Mar Mammal Sci 19(2), 344-362.

Smith, T.G., 1981. Notes on the Bearded Seal, Erignathus barbatus, in the Canadian Arctic. Canadian Technical Report of Fisheries and Aquatic Sciences 1042, 49.

Stabeno, P.J., Bond, N.A., Salo, S.A., 2007. On the recent warming of the southeastern Bering Sea shelf. Deep-Sea Research Part Ii-Topical Studies in Oceanography 54(23), 2599-2618.

Sterling, J.T., Springer, A.M., Iverson, S.J., Johnson, S.P., Pelland, N.A., Johnson, D.S., Lea, M.A., Bond, N.A., 2014. The Sun, Moon, Wind, and Biological Imperative-Shaping Contrasting Wintertime Migration and Foraging Strategies of Adult Male and Female Northern Fur Seals (Callorhinus ursinus). Plos One 9(4).

Stroeve, J., Serreze, M., Drobot, S., Gearheard, S., Holland, M., Maslanik, J., Meier, W., Scambos, T., 2008. Arctic Sea Ice Extent Plummets in 2007. Eos, Transactions American Geophysical Union 89(2), 13.

Suzuki, C.A., Hierlihy, S.L., 1993. Renal clearance of domoic acid in the rat. Food Chem Toxicol 31(10), 701-706.

Todd, E.C.D., 1993. Domoic acid and amnesic shellfish poisoning: A review. Journal of Food Protection 56(1), 69-83.

Torres De La Riva, G., Johnson, C.K., Gulland, F.M.D., Langlois, G.W., Heyning, J.E., Rowles, T.K., Mazet, J.A.K., 2009. Association of an unusual marine mammal mortality event with Pseudo-nitzschia spp. blooms along the southern California coastline. Journal of Wildlife Diseases 45(1), 109-121.

Trainer, V., Sullivan, K., Eberhart, B.T.L., Shuler, A., Hignutt Jr, E., Kiser, J., Eckert, G.L., Shumway, S.E., Morton, S.L., 2014. Enhancing Shellfish Safety in Alaska through Monitoring of Harmful Algae and Their Toxins. Journal of Shellfish Research 33(2), 531-539.

USFWS, 2011. Endangered and threatened wildlife and plants; 12 -month finding on a petition to list the Pacific walrus as endangered or threatened, In: Service, U.S.F.a.W. (Ed.), Federal Register 76, pp. 7634-7679.

Van Dolah, F.M., 2000. Marine algal toxins: Origins, health effects, and their increased occurrence. Environmental Health Perspectives 108, 133-141. Wekell, J.C., Gauglitz, E.J., Barnett, H.J., Hatfield, C.L., Eklund, M., 1994. The Occurrence of Domoic Acid in Razor Clams (Siliqua-Patula), Dungeness Crab (Cancer-Magister), and Anchovies (Engraulis-Mordax). Journal of Shellfish Research 13(2), 587-593.

White, A.W., 1986. High toxin content in the dinoflagellate Gonyaulax excavata in nature. Toxicon 24(6), 605-610. 
1 Wohlgeschaffen, G.D., Mann, K.H., Subba Rao, D.V., Pocklington, R., 1992. Dynamics

2 of the phycotoxin domoic acid: Accumulation and excretion in two commercially

3 important bivalves. Journal of Applied Phycology 4, 297-310.

4 Zeh, J.E., Punt, A.E., 2005. Updated 1978-2001 abundance estimates and their

5 correlations for the Bering-Chukchi-Beaufort Seas stock of bowhead whales. Journal

6 of Cetacean Research Management 7(2), 169-175.

7

8

9

10

11 
Figure 1: Locations where algal toxins were detected in stranded (s) and harvested (h) marine mammals. Red images represent species positive for domoic acid (DA) and purple images represent species positive for saxitoxin (STX). Marine mammal species are listed as follows; A) Humpback whales, B) Bowhead whales, C) Beluga whales, D) Harbor porpoises, E) Northern fur seals, F) Steller sea lions, G) Harbor seals, H) Ringed seals, I) Bearded seals, J) Spotted seals, K) Ribbon seals, L) Pacific walruses, and M) Northern sea otters.

Figure 2: Domoic acid (DA) concentrations quantified in A) feces and gastrointestinal (GI) contents, and B) urine for all Alaskan species sampled. Domoic acid concentrations detected in 10 California sea lions (CSL) exhibiting signs of DA toxicosis (seizures) are included for reference and shown in the box. 


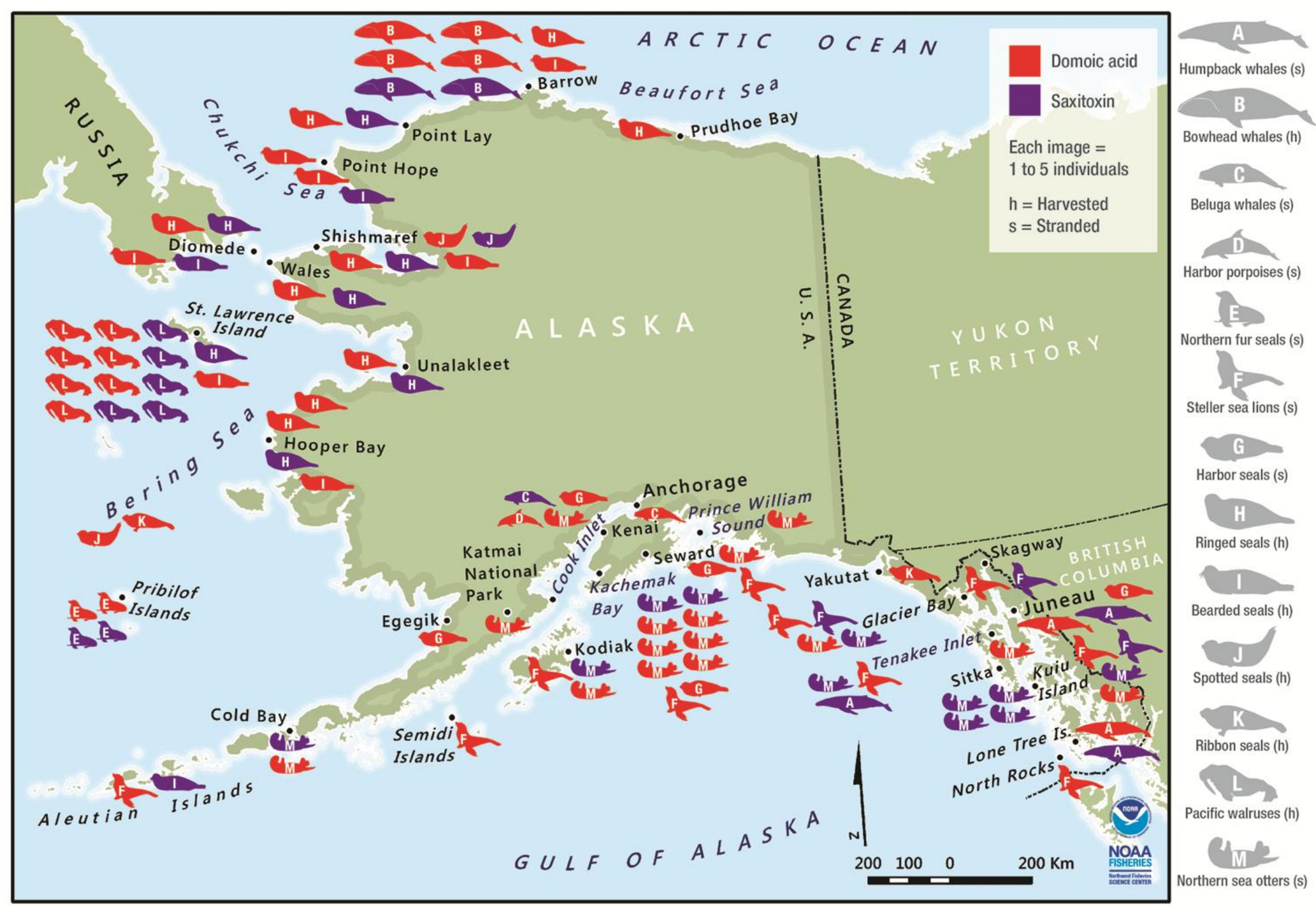
$\overparen{0} \quad$ Figure 2

을

엉

屯

(5)

0

운에

응

층

응

흥
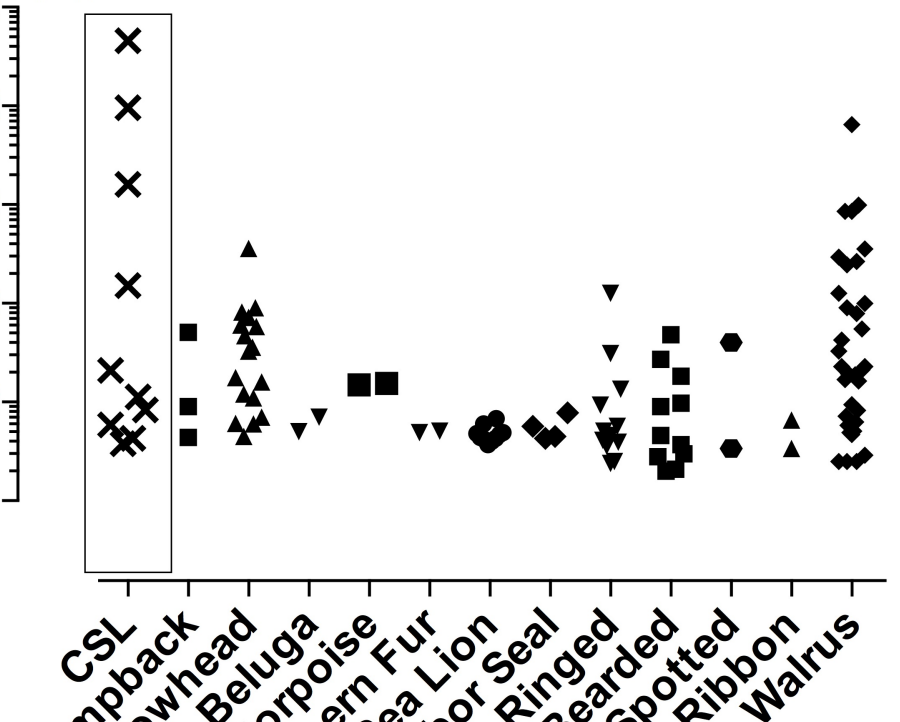

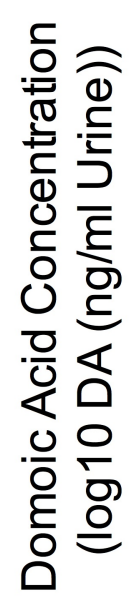

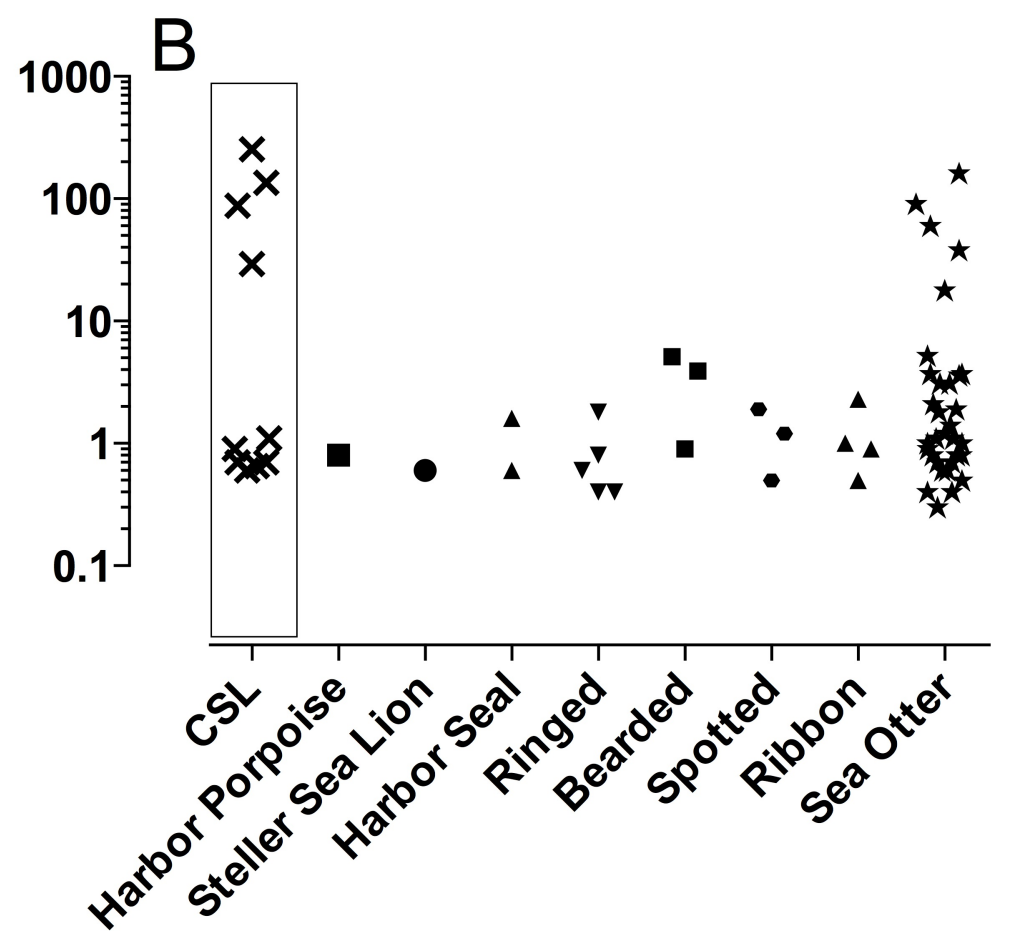

Species 
Table 1: List of species, collection status, period and locations, and total number of animals for each species of the 905 marine mammals sampled in Alaska (AK).

\begin{tabular}{|c|c|c|c|c|}
\hline Species & $\begin{array}{l}\text { Collection } \\
\text { status }\end{array}$ & $\begin{array}{l}\text { Collection } \\
\text { period }\end{array}$ & $\begin{array}{l}\text { Collection } \\
\text { locations }\end{array}$ & $\begin{array}{c}\text { Total \# of } \\
\text { animals }\end{array}$ \\
\hline Humpback & Stranded & $\begin{array}{l}\text { July } 2007 \text { to } \\
\text { Sept. } 2011\end{array}$ & $\begin{array}{l}\text { Kodiak, The AK } \\
\text { Peninsula, } \\
\text { Southeast }\end{array}$ & 8 \\
\hline Bowhead & Harvested & $\begin{array}{l}\text { Spring \& Fall } \\
2006 \text { to } 2011\end{array}$ & Barrow & 25 \\
\hline Beluga & $\begin{array}{l}\text { Stranded \& } \\
\text { Harvested }\end{array}$ & $\begin{array}{l}\text { Sept. } 2005 \text { to } \\
\text { Oct. } 2012\end{array}$ & $\begin{array}{c}\text { Cook Inlet, Hooper } \\
\text { Bay }\end{array}$ & 15 \\
\hline $\begin{array}{l}\text { Harbor } \\
\text { porpoise }\end{array}$ & Stranded & $\begin{array}{l}\text { Aug. } 2008 \text { to } \\
\text { July } 2011\end{array}$ & Cook Inlet & 5 \\
\hline $\begin{array}{l}\text { Northern } \\
\text { fur seal }\end{array}$ & $\begin{array}{l}\text { Harvested \& } \\
\text { Live Capture }\end{array}$ & 2010 & $\begin{array}{l}\text { Saint George \& } \\
\text { Saint Paul Islands }\end{array}$ & 179 \\
\hline $\begin{array}{l}\text { Steller sea } \\
\quad \text { lion }\end{array}$ & Stranded & $\begin{array}{l}\text { May } 2004 \text { to } \\
\text { March } 2013\end{array}$ & Gulf of AK & 42 \\
\hline $\begin{array}{c}\text { Harbor } \\
\text { seal }\end{array}$ & Stranded & $\begin{array}{l}\text { May } 2008 \text { to } \\
\text { Aug. } 2012\end{array}$ & Gulf of AK, Egegik & 9 \\
\hline $\begin{array}{l}\text { Ringed } \\
\text { seal }\end{array}$ & Harvested & $\begin{array}{l}\text { Nov. } 2006 \text { to } \\
\text { Nov. } 2012\end{array}$ & $\begin{array}{l}\text { Barrow, Chukchi } \\
\text { Sea, Bering Sea }\end{array}$ & 113 \\
\hline $\begin{array}{l}\text { Bearded } \\
\text { seal }\end{array}$ & Harvested & $\begin{array}{l}\text { Oct. } 2007 \text { to } \\
\text { June } 2013\end{array}$ & $\begin{array}{l}\text { Barrow, Chukchi } \\
\text { Sea, Bering Sea }\end{array}$ & 55 \\
\hline $\begin{array}{l}\text { Spotted } \\
\text { seal }\end{array}$ & $\begin{array}{l}\text { Harvested \& } \\
\text { Snow Urine }\end{array}$ & $\begin{array}{l}\text { Nov. } 2006 \text { to } \\
\text { Nov. } 11\end{array}$ & $\begin{array}{l}\text { Barrow, Chukchi } \\
\text { Sea, Bering Sea }\end{array}$ & 158 \\
\hline $\begin{array}{l}\text { Ribbon } \\
\text { seal }\end{array}$ & $\begin{array}{l}\text { Harvested \& } \\
\text { Snow Urine }\end{array}$ & $\begin{array}{l}\text { May } 2009 \text { to } \\
\text { Oct. } 2012\end{array}$ & $\begin{array}{c}\text { Barrow, Chukchi } \\
\text { Sea, Bering Sea, } \\
\text { Yakutat }\end{array}$ & 21 \\
\hline $\begin{array}{l}\text { Pacific } \\
\text { walrus }\end{array}$ & Harvested & $\begin{array}{l}\text { May \& June in } \\
2012 \text { \& } 2013\end{array}$ & $\begin{array}{l}\text { Saint Lawrence } \\
\text { Island }\end{array}$ & 82 \\
\hline $\begin{array}{l}\text { Northern } \\
\text { sea otter }\end{array}$ & $\begin{array}{l}\text { Stranded \& Live } \\
\text { Capture }\end{array}$ & $\begin{array}{l}\text { April } 2004 \text { to } \\
\text { May } 2011\end{array}$ & Gulf of AK & 193 \\
\hline
\end{tabular}


Table 2: Summary of the number of domoic acid-positive individuals from 13 species of Alaskan marine mammals, including the sample matrix with the highest concentration. $\mathrm{F}=$ Feces, $\mathrm{SC}=$ Stomach Contents, $\mathrm{S}=$ Serum, $\mathrm{IC}=$ Intestinal Contents, $\mathrm{U}=$ Urine.

\begin{tabular}{|l|c|c|c|c|c|}
\hline \multicolumn{1}{|c|}{ Species } & $\begin{array}{c}\text { Number of } \\
\text { animals }\end{array}$ & $\begin{array}{c}\text { Number } \\
\text { positive }\end{array}$ & $\begin{array}{c}\text { \% } \\
\text { Positive }\end{array}$ & $\begin{array}{c}\text { Max conc. } \\
\text { (ng/g or ml) }\end{array}$ & $\begin{array}{c}\text { Sample } \\
\text { matrix }\end{array}$ \\
\hline Cetaceans & & & & & \\
\hline Humpback whale & 8 & 3 & $38 \%$ & 51 & $\mathrm{~F}$ \\
\hline Bowhead whale & 25 & 17 & $68 \%$ & 359 & $\mathrm{~F}$ \\
\hline Beluga whale & 15 & 2 & $13 \%$ & 7 & $\mathrm{SC}$ \\
\hline Harbor porpoise & 5 & 2 & $40 \%$ & 15 & $\mathrm{~F}$ \\
\hline Otariids & & & & & \\
\hline Northern fur seal & 179 & 8 & $5 \%$ & 14 & $\mathrm{~S}$ \\
\hline Steller sea lion & 44 & 12 & $27 \%$ & 7 & $\mathrm{SC}$ \\
\hline Phocids & & & & & $\mathrm{F}$ \\
\hline Harbor seal & 9 & 6 & $67 \%$ & 8 & $\mathrm{~F}$ \\
\hline Ringed seal & 113 & 19 & $17 \%$ & 127 & $\mathrm{IC}$ \\
\hline Bearded seal & 55 & 14 & $25 \%$ & 48 & $\mathrm{SC}$ \\
\hline Spotted seal & 158 & 5 & $3 \%$ & 40 & $\mathrm{~F}$ \\
\hline Ribbon seal & 21 & 5 & $24 \%$ & 7 & $\mathrm{SC}$ \\
\hline Odobenids & & & & & $\mathrm{U}$ \\
\hline Pacific walrus & 82 & 34 & $41 \%$ & 6,457 & \\
\hline Mustelids & & & & & \\
\hline Northern sea otter & 172 & 43 & $25 \%$ & 162 & \\
\hline & & & & & \\
\hline Total number & 886 & 188 & $21 \%$ & & \\
\hline
\end{tabular}


Table 3: Summary of the number of saxitoxin-positive individuals from 13 species of Alaskan marine mammals, including the sample matrix with the highest concentration. $\mathrm{F}=$ Feces, $\mathrm{SC}=$ Stomach Contents, $\mathrm{IC}=$ Intestinal Contents, $\mathrm{U}=$ Urine; na $=$ not applicable.

\begin{tabular}{|l|c|c|c|c|c|}
\hline \multicolumn{1}{|c|}{ Species } & $\begin{array}{c}\text { Number of } \\
\text { animals }\end{array}$ & $\begin{array}{c}\text { Number } \\
\text { positive }\end{array}$ & $\begin{array}{c}\text { \% } \\
\text { Positive }\end{array}$ & $\begin{array}{c}\text { Max conc. } \\
\text { (ng/g or ml) }\end{array}$ & $\begin{array}{c}\text { Sample } \\
\text { Matrix }\end{array}$ \\
\hline Cetaceans & & & & & \\
\hline Humpback whale & 8 & 4 & $50 \%$ & 62 & $\mathrm{~F}$ \\
\hline Bowhead whale & 25 & 8 & $32 \%$ & 63 & $\mathrm{~F}$ \\
\hline Beluga whale & 12 & 1 & $8 \%$ & 4 & $\mathrm{~F}$ \\
\hline Harbor porpoise & 5 & 0 & $0 \%$ & $\mathrm{na}$ & $\mathrm{na}$ \\
\hline Otariids & & & & & $\mathrm{F}$ \\
\hline Northern fur seal & 179 & 8 & $5 \%$ & 42 & $\mathrm{~F}$ \\
\hline Steller sea lion & 42 & 4 & $10 \%$ & 7 & $\mathrm{na}$ \\
\hline Phocids & & & & & $\mathrm{F}$ \\
\hline Harbor seal & 8 & 0 & $0 \%$ & $\mathrm{na}$ & $\mathrm{IC}$ \\
\hline Ringed seal & 110 & 15 & $14 \%$ & 172 & $\mathrm{na}$ \\
\hline Bearded seal & 44 & 6 & $14 \%$ & 15 & $\mathrm{IC}$ \\
\hline Spotted seal & 145 & 1 & $1 \%$ & 3 & $\mathrm{Ua}$ \\
\hline Ribbon seal & 7 & 0 & $0 \%$ & & \\
\hline Odobenids & & & & & \\
\hline Pacific walrus & 82 & 23 & $28 \%$ & 240 & \\
\hline Mustelids & & & & & \\
\hline Northern sea otter & 163 & 37 & $23 \%$ & 45 & $\mathrm{U}$ \\
\hline & & & & & \\
\hline Total number & 830 & 107 & $13 \%$ & & \\
\hline
\end{tabular}


Table 4: Summary of animals $(\mathrm{N}=46)$ that tested positive for both domoic acid (DA) and saxitoxin (STX) and mean ( $\pm \mathrm{sd}$ ) toxin values (ng/g or ml). Sample matrix includes: $\mathrm{F}=\mathrm{Feces}, \mathrm{SC}=$ Stomach Contents, $\mathrm{IC}=$ Intestinal Contents, and U = Urine.

\begin{tabular}{|l|c|c|c|c|c|}
\hline \multicolumn{1}{|c|}{ Species } & N & DA & STX & Matrix & $\begin{array}{c}\text { Collection } \\
\text { Locations }\end{array}$ \\
\hline Humpback whale & 3 & $21 \pm 26$ & $30 \pm 28$ & $\mathrm{~F}$ & Southeast Alaska \\
\hline Bowhead whale & 6 & $83 \pm 137$ & $48 \pm 11$ & $\mathrm{~F}$ & Barrow \\
\hline Ringed seal & 5 & $6 \pm 2$ & $41 \pm 73$ & $\mathrm{~F} / \mathrm{SC}$ & $\begin{array}{c}\text { Chukchi Sea, } \\
\text { Bering Sea }\end{array}$ \\
\hline Bearded seal & 3 & $11 \pm 14$ & $8 \pm 6$ & $\mathrm{~F} / \mathrm{SC} / \mathrm{U}$ & $\begin{array}{c}\text { Chukchi Sea, } \\
\text { Bering Sea }\end{array}$ \\
\hline Pacific walrus & 20 & $524 \pm 1,432$ & $64 \pm 80$ & IC & $\begin{array}{c}\text { St. Lawrence Island } \\
\text { Kachemak Bay, } \\
\text { Juneau, Glacier Bay }\end{array}$ \\
\hline Northern sea otter & 9 & $2 \pm 2$ & $7 \pm 3$ & $\mathrm{U}$ & \\
\hline Total number & 46 & & & & \\
\hline
\end{tabular}

